\title{
Bases and Foundations of Buildings under Reconstruction
}

P.A. Konovalov

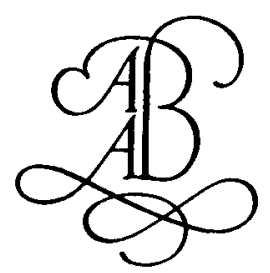

A.A BALKEMA/ROTTERDAM/BROOKFIELD/1998 
Authorization to photocopy items for internal or personal use, or the internal or personal use of specific clients, is granted by A.A. Balkema, Rotterdam, provided that the base fee of US\$1.50 per copy, plus US\$0.10 per page is paid directly to Copyright Clearance Centre, 222 Rosewood Drive, Danvers, MA 01923, USA. For those organisations that have been granted a photocopy licence by $\mathrm{CCC}$, a separate system of payment has been arranged. The fee code for users of the Transactional Reporting Service is: 905410722 7/98 US\$1.50 + US\$0.10.

Translation of : Osnovaniya i fundamenti rekonstruiruemikh Zadanii, $2^{e}$, Stroiizdat, Moscow, 1988. Revised and updated by the author for the English edition in 1996-1997.

Translator: Dr. V.B. Sarma

Translation Editor: Dr. G. Venkatachalam

General Editor: Ms Margaret Majithia

(C) 1998 Copyright Reserved

ISBN 9054107227

A.A. Balkema, P.O. Box 1675, 3000 BR Rotterdam, Netherlands

Fax: +31.10.4135947; E-mail: balkema@balkema.nl

Internet site: http://www.balkema.nl

Distributed in USA and Canada by

A.A. Balkema Publishers, Old Post Road, Brookfield, VT 05036-9704, USA

Fax: 802.276.3837; E-mail: Info@ashgate.com 


\section{PREFACE}

Jobs relating to strengthening of foundations and improving the soils at their base present maximum difficulty in the list of basic construction works involving any type of reconstruction. There are no standard methods in this field of construction for planners and builders to adopt. Each particular situation requires taking into account not only specific engineering-geological conditions, but also the experience of professionals at home and abroad. The author has summarised such experience in the reconstruction of buildings and structures for which strengthening of foundations was not necessary and those for which such strengthening was absolutely mandatory.

The question of increasing the stress on soils compressed under the load of in-service structures by increasing the number of upper storeys or reconstruction, which results in added stress, without strengthening the bases and foundations is considered. Analysis of experience in superstorey construction and reconstruction of different types of structures located in different engineering-geological situations, enabled fixing the procedure for investigating construction of the structure per se, volume and content of engineering-geological investigation of foundations, compilation of technical recommendations for increasing loads on soils, basic safety requirements etc.

In stating the specialities of planning bases and foundations for buildings and structures under reconstruction, a new method of computing the allowable stress on soils at the base already compressed under longstanding loads is suggested. The recommended method is economically very efficient for designing and reconstructing structures since its adoption in a number of cases has precluded the troublesome jobs of artificially strengthening the soils at the base and increasing the size of foundations.

More material pertinent to experience in reconstruction in situations wherein improvement of the bases and strengthening of foundations was imperative, has been included in this enlarged, second edition of Bases and Foundations of Buildings under Reconstruction. 
iv

Numerous articles, handbooks and textbooks pertaining to foundations of buildings under reconstruction have been published since the second edition of this volume came on the market. Thus some additional material and clarifications have been included in the English translation and the list of References updated.

The author thanks A.G. Roitman who collaborated in the design method for bases of buildings with superstorey construction and N.S. Nikiforova, V.G. Smirnov, N.V. Vlasova, A.A. Beztsenna and L.V. Terekhova who assisted in the preparation of the manuscript. Sincere gratitude is expressed to I.T. Cherkasov (Russia) and Dz. P. Manyan (France) for invaluable comments while reviewing the non-English editions of this book. 


\section{Contents}

Preface

1. Reasons for Strengthening Bases and Foundations of Buildings

1. Deformations of In-service Buildings

2. Load Increase Due to Building Additional Storey and Reconstruction

3. Standardising Stress Intensity on Foundation Soils

2. Condition of Bases and Foundations of Buildings under Reconstruction

1. Effect of Service Period of Buildings on Deterioration of Foundations

2. Design Parameters of Foundations

3. Changes in Stress on Foundation Soils after Reconstruction of Buildings

4. Utilisation of Reserve Bearing Capacity of Foundations in Reconstructions

5. Experience in Prescribing Permissible Stress on Foundation Soils after Reconstruction

3. Behavioural Features of Foundations of In-Service Buildings

1. Nature of Soil Reinforcement 55

2. Depth of Compressible Layer of Base 58

3. Variation in Moisture Regime of Soil and Water Table

4. Consolidation of Foundation Soils under Load 73

5. Effect of Long-term Loads on Mechanical Properties of Foundation Soils

4. Engineering-Geological Investigations and Inspections of Foundations of Reconstructed Buildings 
2. Investigation of Foundation Soils 93

3. Inspection of Foundations 100

4. Summary of Technical Feasibility of Reconstructing Buildings with Increased Loads $\quad 106$

5. Designing Bases and Foundations of Buildings under Reconstruction

1. Sequence of Works while Designing Bases and Foundations

2. Summation of Loads for Computation of Foundations

3. Determination of Allowable Stress on Foundation Soils Compressed under Long-term Loading Conditions

4. Verification of Foundation Strength 115

5. Design of Bases According to Ultimate State 119

6. Reinforcement of Foundations on Natural Base 127

1. Strengthening Foundations 127

2. Increasing Foundation Bearing Area 132

3. Deepening Foundations: Underpinning Columns of a New Foundation

4. Construction of Foundation Mats under a Building 140

5. Introduction of Additional Supports

7. Utilization of Piles for Reinforcing Foundations 144

1. Behaviour of Cast-in-situ Piles under the Building 144

2. Reinforcing Foundations with Driven Piles 149

3. Bored Jet Grout Piles 164

4. Slot Foundations 169

5. Partial Replacement of Pile Foundations 171

8. Stabilisation of Soils 173

1. Cementation 173

2. Silicification 174

3. Electrochemical Stabilisation $\quad 176$

4. Thermal Stabilisation 178

5. Strengthening and Lifting Deformed Foundations by High-pressure Jet Grouting $\quad 179$

6. Jet Grouting: Applications 181

9. Special Features of Construction Operations Related to Substructure Works to be Carried out under Reconstruction 187

1. Effective Methods of Destroying Old Foundations 187 
2. Methods for Restoration of Waterproofing 195

3. Installation of Piles and Sheet Piles Adjacent to Structures in Service

4. Deepening Underground Facilities of Buildings 210

5. Construction Works for Lowering Water Table and for Water Drainage

6. Safety Regulations in Reconstruction Works 223

Conclusions

References 


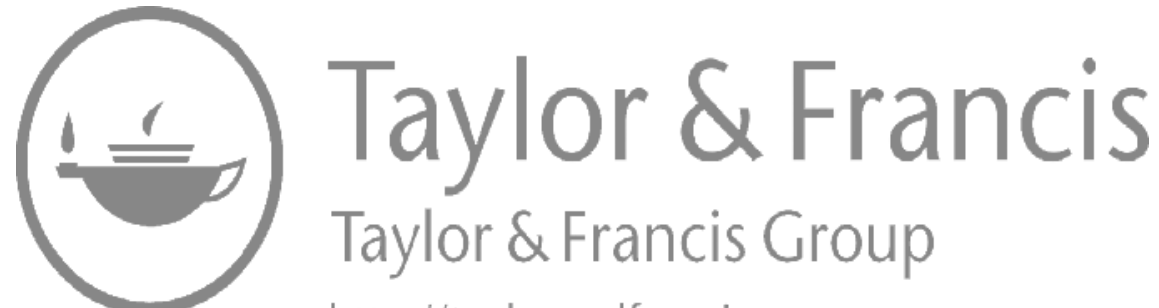
http://taylorandfrancis.com 


\section{1}

\section{Reasons for Strengthening Bases and Foundations of Buildings}

\section{DEFORMATIONS OF IN-SERVICE BUILDINGS}

The reconstruction work of any building or structure is preceded by the investigative stage wherein not only the status of soils in the bases, foundations and the superstructure is ascertained, but also the nature and magnitude of their settlements throughout their entire service period. In situations wherein the total or differential settlements of the structures are considerable, it is necessary to understand their causes. The future performance of buildings under the action of additional loads on bases under reconstruction depends on this.

The Research Institute for Bases and Underground Constructions is presently doing a great deal of investigative work on the settlement of buildings and structures used for various purposes in differing engineering-geological conditions.

Highly intensive investigative work has already been done along this line by R.A. Tokar, D.E. Polshin, K.E. Egorov, Yu. M. Abelev, V.V. Mikheev, N. Ya. Rudnitskii, P.I. Brait and others. Analysis of their data revealed that the basic laws governing the development of deformations of buildings and structures could be reduced to the following:

1. Settlement of structures as a result of consolidation of soil in the bases under the action of loads and the time for its stabilisation depend on the type and condition of soils and on the rate of increase in stress during construction. Deformation of sandy and stiff clay bases of buildings and structures can be considered as almost completed during the construction period. The process of stabilisation of settlement in clays with a liquidity index $I_{L} \geq 0$ extends over a long period and hence settlement during the construction period can be assumed to be $50 \%$ of the total.

2. Settlement during the construction period is associated with the rate of increase in load. With increase in rate of loading, the proportion of settlement during this period will reduce. 
3. Basically, uneven settlement of the building takes place during the construction period. Maximum difference in settlements depends on the average; with increase in average settlement, the difference between settlements increases and tends to reach the limiting value determined by the rigidity of the building.

4. Actual settlements of buildings and structures are generally $25-30 \%$ of the calculated values and only in isolated instances may reach $70-80 \%$. Exceptions are buildings erected on thick saturated weak clays wherein, according to the data of B.D. Vasilev, B.I. Dalmatov, S.N. Sotnikov and others, the actual settlement exceeds not only that computed, but even in a number of cases the allowable limits as per the codes. Further, field and model studies have shown that the faster a structure is built, the greater should be the anticipated deformation. Hence under speedy construction, when consolidation lags behind increase in pressure, it is appropriate to consider the possibility of increase in deformation.

An experiment to investigate deformations of foundations of buildings was carried out by NIIOSP and Mosproekt-I in Moscow in Block no. 58, Fili-Mazilov. Two similar prefabricated 5-storeyed residential houses of series 1-510 (Block nos. 17 and 18) had been built on the same ground but with foundations of different widths.

The foundation soil was fine and silty sand with $e=0.7-0.71 ; W=5.4-$ $8 \% ; S_{r}=0.2-0.3 ; \rho_{0}=1.63-1.7 \mathrm{t} / \mathrm{m}^{3}$, with modulus of deformation $E=30$ $\mathrm{MPa}$ for sands and $8 \mathrm{MPa}$ for loamy soils.

In the calculation for Block no. 17 (curve 1 in Fig. 1) the value of allowable pressure $R$ was taken as $0.25 \mathrm{MPa}$, base width of footings for external walls $1.4 \mathrm{~m}$ and for internal longitudinal walls $2 \mathrm{~m}$. Computed

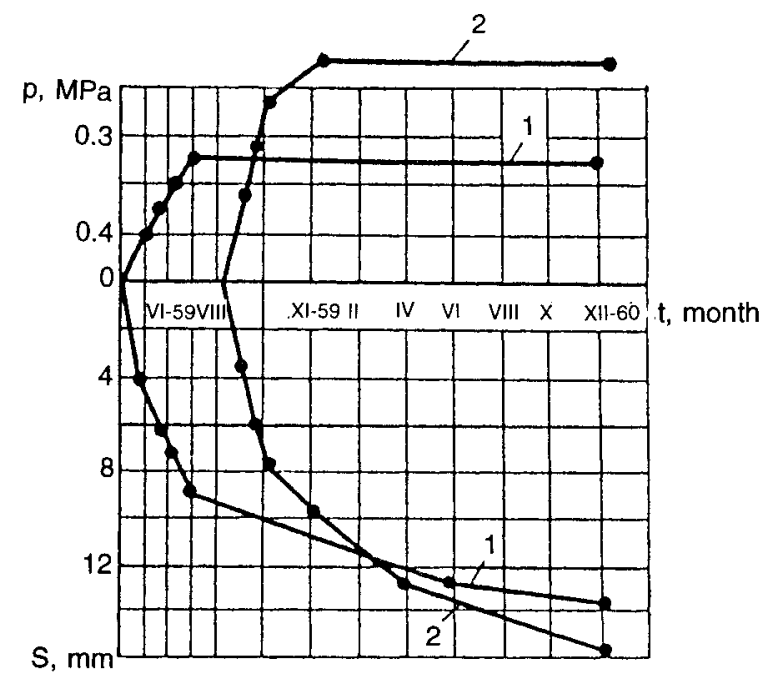

Fig. 1 Settlement over time of 5-storeyed buildings under identical soil conditions. 
settlements under these were correspondingly $S_{h}^{R}=6.3 \mathrm{~mm}$ and $S_{b}^{R}=9.2$ $\mathrm{mm}$. For Block no. 18 (curve 2) the foundation width for external walls was $0.6 \mathrm{~m}$ and internal longitudinal walls was $0.8 \mathrm{~m}$; stress on the soil base worked out to $0.45 \mathrm{MPa}$ (allowable pressure as per SNiP, $R=0.3$ $\mathrm{MPa}$ ).

The following foundation settlements were expected: For external walls $S_{h}^{R}=21.3 \mathrm{~mm}$ and for internal walls $S_{b}^{R}=34.6 \mathrm{~mm}$. But actual settlements turned out to be less (see Fig. 1). Based on experimental results the following conclusions were drawn:

-Actual settlements of the buildings during the observation period were $70 \%$ less than the computed values.

-Increase in settlement was not proportional to the decrease in width of the foundation. Thus on decreasing the foundation width by a factor of 2.5 , the increase in settlement was only $10-15 \%$, i.e., with considerable decrease in foundation width, only a small increase in settlement was obtained (as per calculations based on the method of layer-wise summation).

Causes of considerable deformation of buildings and structures requiring strengthening and reinforcing bases and foundations not only during the reconstruction period, but also during the normal in-service period, thus appear to be mistakes committed during the exploration, design, construction and service stages, in addition to objective factors (changes in hydrogeological conditions, dynamic and seismic actions etc.).

Execution of extensive exploration work in new micro-regions where standard structures are built has sometimes led to hasty and incomplete study of the characteristics of the engineering-geological and hydrogeological conditions of the construction site. Insufficient information about the physicomechanical characteristics of soils at the base is often supplemented by data from various tables of soil characteristics. These tables give the general properties of a variety of soils for the entire country or individual regions, but do not give a total picture of the deformation and strength characteristics of soils at specific sites. Using them has led to errors and resultant serious consequences, as happened in the construction of a 5-storeyed apartment building in Tula for example. A standard (series P-447, C-29) 5-storeyed, 6-sectioned, 96-units residential brick building with longitudinal load-bearing walls, basement, and shops on the 1st floor $90 \%$ completed up to the roof slab, failed throughout the entire height of five floors in one section (Fig. 2a).

Prefabricated reinforced concrete block foundations embedded $20 \mathrm{~cm}$ relative to the floor of the basement settled in the middle of the building along external axis $C$ up to $54 \mathrm{~cm}$ and displaced inside the basement up to $70 \mathrm{~cm}$. As there was no concrete support under the basement floor 
(a)

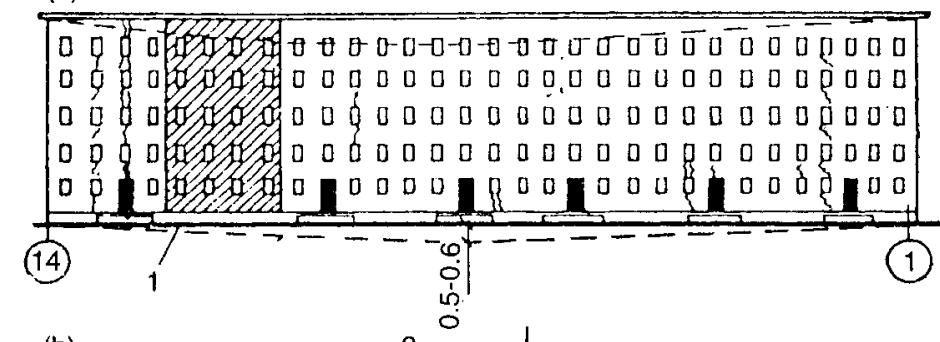

(b)
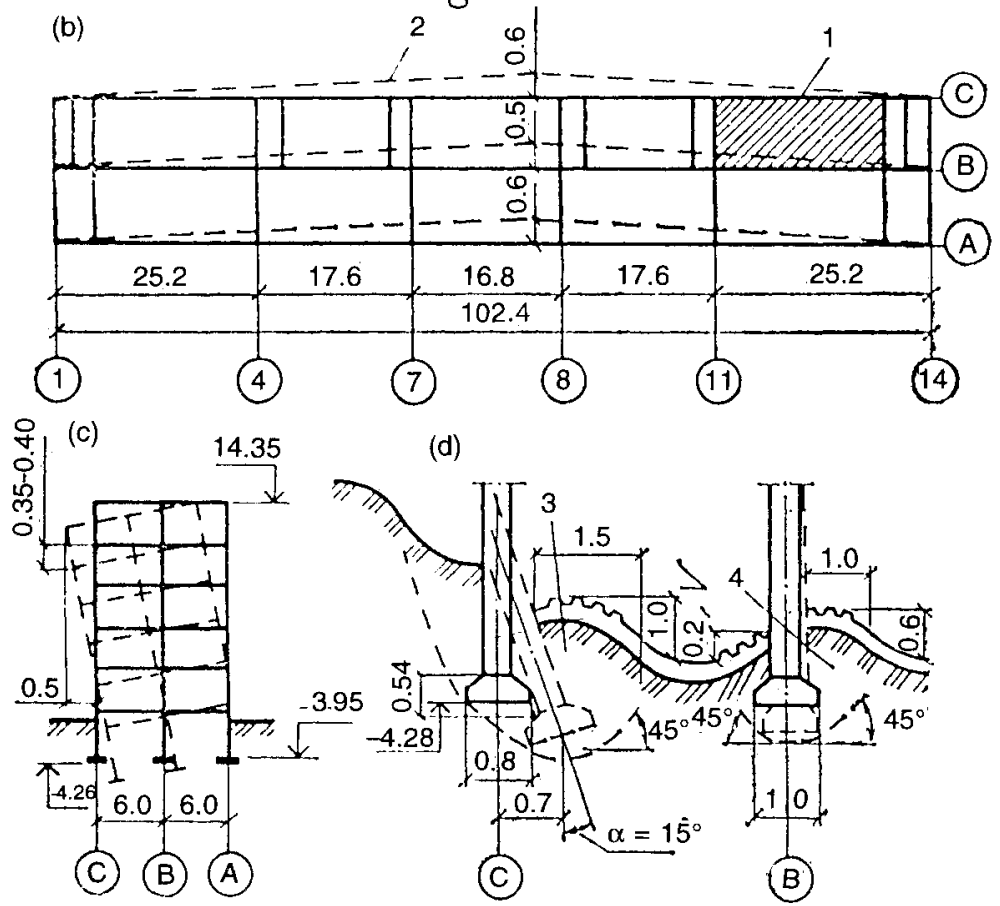

Fig. 2 A, B, C: Catastrophic deformations of 5-storeyed residential building in Tula.

1-collapsed part of wall; 2-wall tilt; 3-soil swelling; 4-basement; 1-14 (circled)-lateral axes of building.

throughout the length of the building, displacements and settlements of the foundations were not uniform. These deformations led to swell formation due to soil heave at the basement, which attained a width of 1.2$1.5 \mathrm{~m}$ and a height of $0.60-1.0 \mathrm{~m}$. Along the middle axis, $B$, maximum foundation settlement was $54 \mathrm{~cm}$ with movement towards the $A$ axis up to $20 \mathrm{~cm}$ (see Fig. 2, b, c, d). The swells due to soil heave were located on either side of the basement wall. No settlement or displacement of foundation was observed along axis $A$. 
As a result of the differential settlement of the foundation under the longitudinal walls, the rigid frame of the building rotated in a crosssectional direction on the line passing through axis $C$ of the foundation. Thus the top portion of the building wall shifted $50-60 \mathrm{~cm}$ from the pedestal walls. Wide cracks appeared in the external walls of the building.

The basic cause for the catastrophic deformation of this apartment building was improper assessment of the soil properties during investigation of the soils in the base. The strength characteristics of soils given by $\mathrm{SNiP}$ for designing foundations had been assumed by the investigators who failed to note that the tables are applicable only to Quaternary deposits. In the base of this building, however, there were clay soils of the Lower Carboniferous which have a marked tendency to lose their strength and to deform upon excavation and wetting.

Further, the designers did not critically evaluate the higher values of strength characteristics given by the site investigators. So they in turn took the value of $R=0.5 \mathrm{MPa}$ and erected the building on prefabricated block reinforced concrete foundations with width $b=0.8 \mathrm{~m}$ along axes $A$ and $C$, and $b=1 \mathrm{~m}$ along axis $B$ with the spacing of foundation blocks $c=10-15 \mathrm{~cm}$. Stress intensity under the footing of the foundation according to the design was not to exceed 0.47 MPa. At the time of the catastrophe the stress on the soil was only $0.35 \mathrm{MPa}$. But all the standard buildings in the vicinity under similar soil conditions had been designed for a safe bearing pressure of $0.25 \mathrm{MPa}$ and their deformations never reached the maximum permissible values.

The errors of the site investigators and designers were further compounded during construction by poor levelling of the soil around the building; the ground surface sloped towards the building which resulted in rain-water seepage into the basement because of inadequately compacted backfill material and thus oversaturation of soils in the base. Due to the absence of a concrete support under the basement floor, the basement walls began to function as retaining walls, with a small embedment of the front side and increased horizontal pressure of the saturated earth backfill on the other side. The designers did not take into consideration the possible changes in mode of working of the basement during the construction period, which is essential as per the building code. Given the extensive damage to the construction, the building had to be dismantled.

Side by side with improper assessment of soil properties during investigations, instances of non-detection of highly compressible clay layers and especially of buried peat or peaty soils are not uncommon. Occurring in the bases of buildings and structures and even beyond the boundaries of the compressible layer, clay and peaty soils can cause long-term and considerable differential settlement. 
In practice, the depth of exploratory bores in site investigative work for multistoreyed residential buildings (low and medium heights) does not exceed 8-10 $\mathrm{m}$, which is considered sufficient for characterising the soil properties and for carrying out the necessary design of bases and foundations. However, such an approach is not justifiable when the buildings and structures are erected on peaty deposits which contain plant residues (relative content in the mass of the mineral portion, $I_{\text {rel }}>0.1$ ), including layers, bands and lenses of buried peat.

One year after a 3-storeyed brick masonry building was given over for occupancy, differential settlements that increased over time were observed. A study of technical documents revealed that a thick layer of stiff plastic, low compressibility, loamy marine soil was present with an allowable pressure of $R=0.20 \mathrm{MPa}$. Actual pressure on the bottom of the foundation was not more than $R=0.18 \mathrm{MPa}$. The quality of the construction of the superstructure could not be faulted. Yet settlement continued to increase and so it was decided that additional engineering-geological investigations were necessary. A borehole $15 \mathrm{~m}$ deep was drilled (previous depth of drilling no more than $8 \mathrm{~m}$ ) and a lens of buried, undecomposed peat $6 \mathrm{~m}$ plus in thickness and extensive in plane was discovered. The non-detection of a highly compressible soil at the investigative stage was the cause of the building's deformation (Fig. 3).

Forseeing the repetition of such situations, the Manual for Design of Foundations for Buildings and Structures (Stroiizdat, Moscow, 1986) has stipulated that if under particular excavations, layers, bands or lenses of peaty soils and buried peat are observed, additional exploration must be done to determine their thickness and extent in plane. Exploration should comprise a depth of not less than the width of the building nor more than $20 \mathrm{~m}$. This requirement has been included in the new $\mathrm{SNiP}$ for engineering investigations for constructions.

Insufficient volume of excavation or

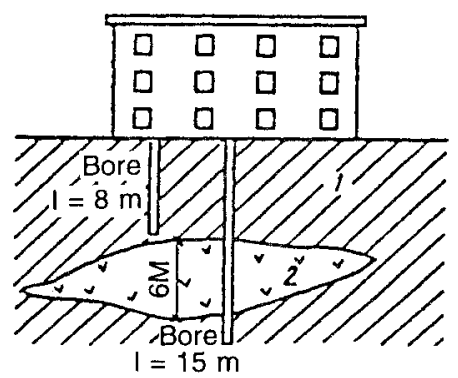

Fig. 3 Engineering-geological cross-section of base of deformed building. 1 -stiff plastic marine loams; 2-peat. incorrect placement of such within the boundary of the building may lead to wrong assessment of properties of soils at the base, as a result of which the building loses its suitability for utilisation. The uneven and long-term settlements of a 3-storeyed residential building in Pskov exemplifies this. During investigation by borings drilled around the building, it was established that the layers of soil in the base were saturated, the upper layers consisting of vegetative and organic residues with a modulus 
of deformation $E \approx 4 \mathrm{MPa}$. At a depth of 9-12 $\mathrm{m}$ a limestone roofing was observed. It was decided to construct the building on strip footings laid on a compacted sand pad of $1 \mathrm{~m}$ thickness.

Dangerous deformation of the building was not seen during the construction period nor during the early stages of service, but became apparent along the facade of the building, especially at the ends, after some years. Progressively opening cracks had formed and shortly thereafter settlement of the building exceeded the permissible limit by 1.5-2 times. It was found that the right side of the building had separated from the rest. Maximum crack width reached $40 \mathrm{~mm}$. Geodesic observations established that settlements had not stabilised over time. Safety concerns prompted shifting the residents from the building.

To ascertain the causes of the deformations of the building, local investigative organisations undertook extensive additional engineering-geological exploration. Only then was it established that the building was located precisely on a dismantled fort wall of a city from the Middle Ages, while the foundation of the facade wall of the building lay atop the backfill material of the fort wall. Bores located in this layer of backfill material during preliminary investigations revealed that it comprised organomineral fill soils (Fig. 4).

In all probability, during the earlier period of utilisation of the building compression of the fill material under the sand pad took place and settlement of the building was uniform. But after the top layer of the base had densified, the influence of the rigid masonry material of the fort wall located just 1.0-1.5 m below the bottom of the foundation may have come into effect. Settlement of the foundation located on the backfill material continued but in the middle part of the building ceased. Such an uneven settlement of the building led to numerous cracks near the window openings and at the junction of the longitudinal and cross walls as well as tearing away of the right side corner of the
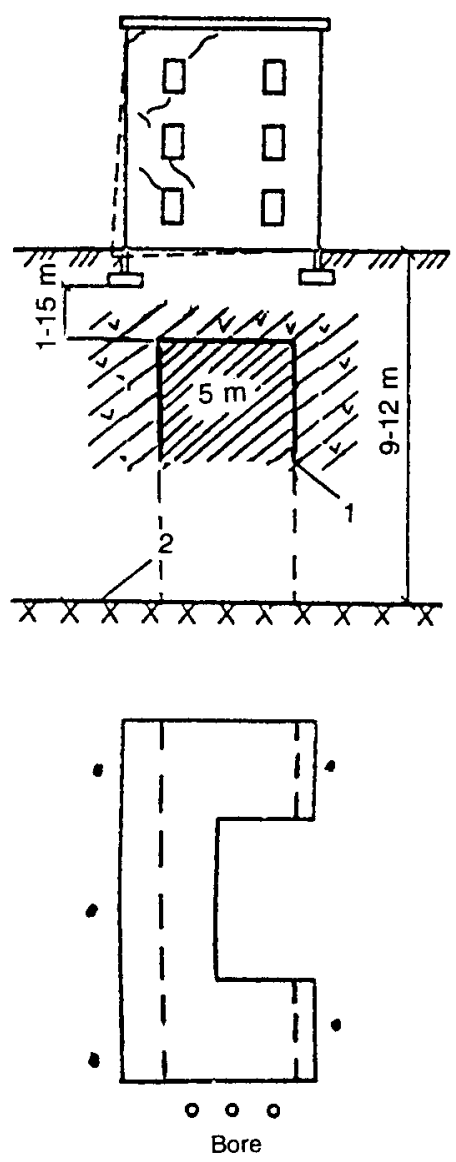

Fig. 4 Deformations of 3-storeyed residential building in Pskov. 1-fort wall in limestone and flagstone; 2-limestone. 
building. Based on the author's advice, the foundation of the building was strengthened by bored injection piles.

Piles $169 \mathrm{~mm}$ in diameter were drilled with a slight inclination to the vertical at intervals of $1.8 \mathrm{~m}$ along the length of the strip footing. All the piles were taken into the limestone layer at the bottom. After this treatment settlement of the building stopped and upon completion of repairs, the building was again given for occupancy.

That planners should aspire to an economical solution to foundation construction is natural and understandable. On average, the cost of the foundation works out to $10 \%$ of the cost of the building. In complex engineering-geological conditions, however, this figure may go up by 1.5-2.0 times. Nevertheless, an economical solution to construction of bases and foundations should not be realised at the cost of reducing their safety, as happened in one structure built in Novgorod.

The construction site lay in the environs of the floodplain of the Volkhov River, consisting of complex plastic, water-saturated, peaty soils (total thickness $7 \mathrm{~m}$ ); at places the peat or silt was covered by fill material up to $1 \mathrm{~m}$ thick. In this case, instead of adopting pile foundations to penetrate through the entire thickness of highly compressible silts to rest on the stronger lower layers, the planners adopted the cheaper strip and discrete foundations on a sand pad only 1.2 to $2.5 \mathrm{~m}$ in thickness. Knowing the predictions for settlement on such a base, the planners ought to have expected considerable deformation which, as a matter of fact, proved far worse than could have been expected.

Several violations occurred during construction work on the sand pad. Sand was placed throughout its thickness with no compaction whatsoever, part of the work was done in winter and hence snow fell into the sand pad etc. Even after several years, when the density of sand in situ was determined by the penetration method, loose sand was found in 6 of the 20 probes. Further, the engineers took up construction without first checking the stabilisation of the settlement of peat under the weight of the fill. The distance from the bottom of the foundation to the top of the peat or peaty soil for a goodly number of structures built by the industry was 1.3-2.0 m, i.e., equal to or slightly wider than the width of the foundation. Given such a situation, additional stress on the top of weak soils exceeded their bearing capacity, which instantly told on the values of total sand, uneven settlement of structures and the status of the superstructure. After 12 to 16 years of service the average settlements of three blocks of the industry were respectively 260,310 and $550 \mathrm{~mm}$. Development of settlements of the buildings over time is shown in Figure 5 .

As a result of uneven settlements in the brickworks of the buildings, particularly in the socle portion and further above up to a height of 1.5$2.5 \mathrm{~m}$, cracks open at the top developed. Through the working of a hole it 
(a)

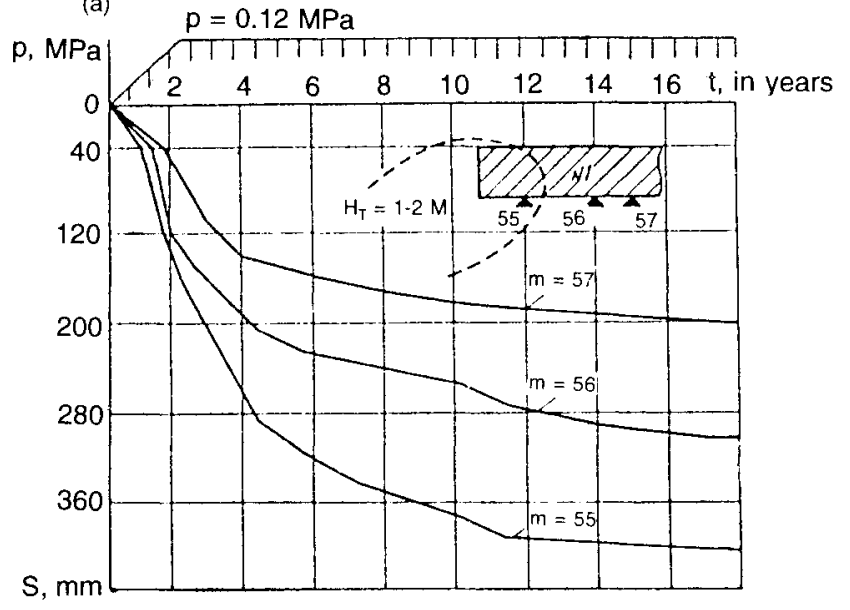

(b)

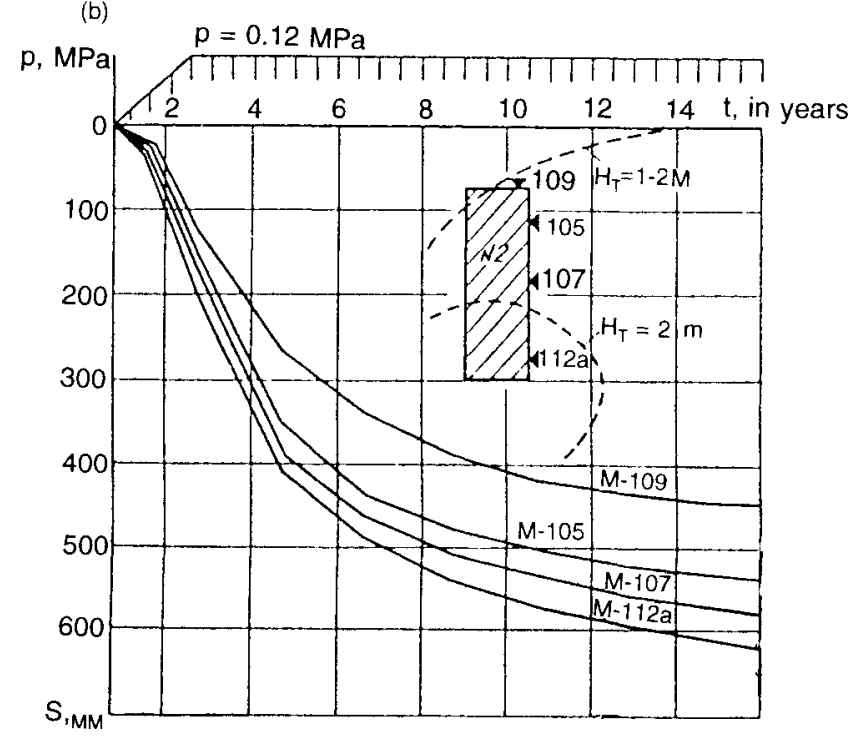

Fig. 5 Settlement of buildings no. 1(a) and 2(b) of an industry in Novgorod on peaty soils over time. Broken lines indicate contour of peat layer.

was found that these cracks extended even into the strip footing. Even after systematic binding the cracks reappeared. Some buildings have had to be repaired and strengthened several times. Analysis of the nature of settlement of buildings over the past five years showed that stabilisation has yet to start. Annual increase in settlement is on average $10 \mathrm{~mm}$; there has been no increase in differential settlement. 
In spite of considerable study of the problems of planning, building and service of buildings and structures on fill soils, to date most such buildings suffer a considerable amount of uneven settlement, leading to failure conditions. This happens especially when the planners fail to foresee or ignore the need for undertaking specific constructional measures in buildings to be erected on fill soils.

In investigations beneath a 2-storeyed building in Orekhovo-Zuevo, at a depth of $1.5 \mathrm{~m}$ a layer of fill material $1 \mathrm{~m}$ thick comprising a mixture of construction and domestic garbage, including organic residue, was encountered. Below this lay a layer of dense fine and medium alluvial sand 5-8 $\mathrm{m}$ in thickness. In the engineering-geological investigations report it was noted that the fill soils were not suitable as bases for the foundations. Nevertheless, in the drawings the base slabs of the boiler are located directly on the fill soil. Further, the builders laid the foundation without requesting an examination of the base soils by the project authorities or investigators.

After one year, cracks up to $10 \mathrm{~mm}$ wide developed in the brick masonry of the horizontal flues adjoining the boiler due to a $50-\mathrm{mm}$ tear in the boiler foundation. The foundations of the pump units tilted and their cast-iron bed plates broke. Intensive wetting of the fill material over the entire depth due to non-repair of water mains was the cause of these deformations. This led to self-compaction of the fill material. Collapse of soils in the base was further exacerbated by the vibratory action of the eccentric pump located in the vicinity of the boiler.

Thus the mistake made during planning resulted in the closure of the boiler unit for some time and additional costly repairs were needed for strengthening the foundation. In erecting buildings on fill materials it is necessary to thoroughly examine their specific features: non-homogeneity of soils, non-uniform compressibility, possibility of self-compaction under their own weight and due to vibrations from working equipment, changes in the hydrogeological regime and flooding.

Mistakes not seen during the construction period, especially while erecting buildings and structures in complex engineering-geological conditions, have often necessitated reinforcement of soils and/or strengthening of foundations. In one region in Moscow where massive construction was going on, a 12-storeyed panelled building calling for load-bearing cross walls in the construction scheme was undertaken. Investigations showed that the surface fill material of $3.5-4.0 \mathrm{~m}$ thickness overlay alluvial deposits of loamy soils, peats, sapropels, which possess low bearing capacity and high deformability. The latter were underlain, at a depth of 10-18 $\mathrm{m}$, by a thick sand layer. The project design called for pile foundations $12 \mathrm{~m}$ long. Since the sand layers were located at various depths the pile tips in the building area were taken into the sand but in other parts 
of the site, due to bad investigation, taken only into the centre of the sapropel layer.

Already during the construction period uneven settlements of the building occurred in a transverse direction. To wit, within 2 months from commencement of construction, settlements of 4.7 and $2.2 \mathrm{~cm}$ were recorded along one axis, which corresponds to a transverse distortion of 0.002 . Unevenness of settlement continued to increase subsequently. Accurate predictions, based on the increasing settlement, indicated that the difference in transverse deformation might reach $12-13 \mathrm{~cm}$ or 0.012 , which considerably exceeds the allowable values as per SNiP 2.02.01-83.

Uneven settlements led to twisting of the building with the development of additional forces in the internal and external panels and likewise in the junctions/connections between panels. The additional work of strengthening the building foundations became inevitable (see Chapter 7).

In recent years quite a number of cases have been recorded of development of uneven and considerable settlements of in-service buildings due to insufficient depth of pile penetration. The reason for this is improper selection of pile-driving equipment. It is noteworthy that inadequate penetration of piles is frequently observed in structures in areas of alluvial soil. Alluvial sand, transported hydromechanically, is generally placed in the floodplains of rivers or in marshy lands for the purpose of upgrading the site and preparing a reliable base for construction.

Before sand placement, surficial peat, silt and sapropel are to be removed and a topographic survey done preliminary to preparation of a contour map of the marshy area. More often, neither is done. Consequently, highly compressible soils are found under a densely laid layer of alluvial sands. Planners usually provide for pile cutting through these soils in order to reduce the anticipated settlement of the building or structure. However, this decision of the planners is often not achieved by the builders. As we showed in an earlier work [1], in the process of driving the pile with the standard pile-driving equipment (example: diesel hammer) a moment will come when the tip of the pile reaches the buried peat layer and the energy of the blow is nullified by the elastic deformation of the peaty layer. In spite of further continuous driving, the pile will not penetrate further. In such piles the head generally breaks and engineers take this condition as 'refusal' and cut off the top.

So the load from the building is transferred by piles of insufficient penetration to the surface of highly compressible layers. That is why buildings and structures experience impermissible large settlements, resulting in loss of their normal functioning and thus necessitating their reconstruction. This happened in the case of a 9-storeyed large panelled residential building constructed on alluvial ground in one of the cities on 
the Volga. After 5 years of service, the wooden pavement blocks of this building had settled $75 \mathrm{~cm}$, which is 7.5 times the permissible (code) value. The uneven nature of the settlement led to formation of cracks in the construction.

Settlement of machines in a paper mill near Imatra (Finland) due to underdriven piles reached $150 \mathrm{~mm}$. To rectify the consequent tilt, it was necessary to carry out extensive complex works at huge expenditure.

Prohibition of utilising agricultural lands for construction purposes has necessitated occupying stretches of land considered unsuitable for construction; thus saturated clays and organomineral soils (silts or peaty soils), distinguished by long-term compaction under load, serve as the base for foundations. Having a very low coefficient of permeability and high compressibility, these soils will predetermine large settlements extending over decades to the structures and buildings erected on them. Their speciality is not linked with this. If on bases consisting of such soils the external loads are applied at a comparatively faster rate, then an unstable condition may arise in them as a result of excess pore pressure development. Such soils may be considered ideally cohesive but the bearing capacity of such bases can only be determined by calculation of cohesion, $c$. If in the computation of bases their non-stable condition is not taken into account, then as per SNiP 2.02.01-83 loss of bearing capacity may result, followed by expulsion of soil from beneath the base of the foundation and serious deformation to the superstructure.

A characteristic exemplification of the aforesaid is the catastrophic deformation of a 5-storeyed, 6-sectional, 56-units building in Sumgait, with utility lines set up in the basement and departmental stores on the 1st floor. The longitudinal walls were load-bearing and their foundations precast reinforced cement blocks $1.4 \mathrm{~m}$ wide along the external axis and $2.4 \mathrm{~m}$ along the middle axis. The base was highly compressible, saturated silty clay with $e=1.1, \phi=13^{\circ}, c=0.02 \mathrm{MPa}$. The allowable bearing capacity of these soils was taken as $R=0.15 \mathrm{MPa}$. Average stress intensity at the level of the foundation base was $p=0.13 \mathrm{MPa}$.

When the basic construction work of the building up to 5 storeys had been completed (except for the roof), in approximately $2 / 3$ of the building increasing deformations developed with tilting of its frame in the direction of axis $A$. Construction work was halted, instrumentation for observing the deformation set up and a safety zone demarcated around the building zone. Observations over a 10-day period revealed that settlements along axis $A$ were $61.92 \mathrm{~cm}$ and the building tilt from the vertical towards that axis $122 \mathrm{~cm}$ (Fig. 6, a). Foundation settlements were found to be differential not only in the lateral direction, but also along the length; hence the frame deformed with a slight rotation along the 


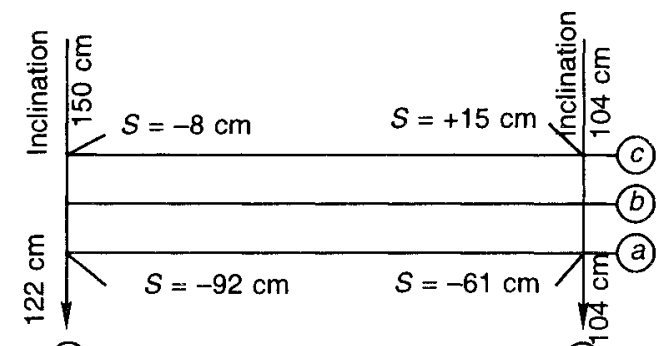

(1)

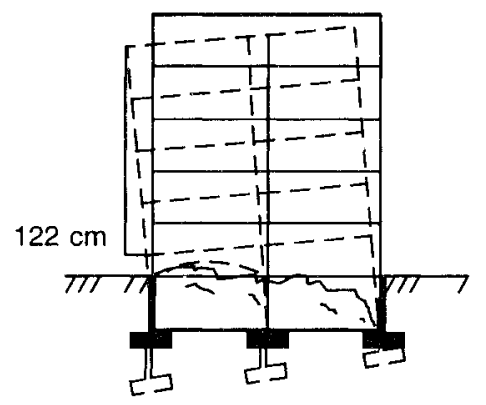

(b) (a)

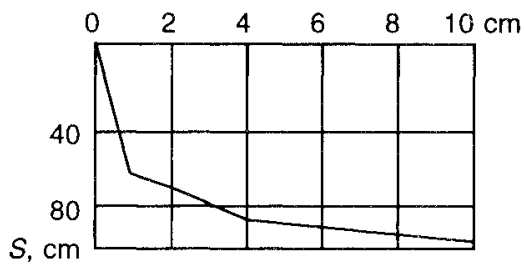

(c)

Fig. 6 Deformations of residential building due to loss of stability of soil at base.

longitudinal direction. The process of settlement development of one part of the building over time is depicted in Figure 6 (c).

In spite of the building's considerable tilt, no destruction was observed in the superstructure above ground level. This is explained by the high rigidity of the structure, created by the presence of antiseismic reinforced concrete bands at each floor level. Opening of the base near the external walls and likewise inspection of the basement housing utilities revealed that the walls of the latter and the foundation blocks had experienced the same tilt as the walls of the building. The basement bulged out along the longitudinal and cross walls and soil works developed which reached the basement floor, breaking it in some places (Fig. 6, b). Stress intensity at the foundation base level at the time of the catastrophe was $p=0.12 \mathrm{MPa}$.

In accordance with SNiP 2.02.01-83, vertical limiting load $N_{\text {ult }}$ in $\mathrm{kN} / \mathrm{m}$ of the base, carried by slowly consolidating saturated soils for strip footings, is computed by the formula

$$
N_{\mathrm{ult}}=\vec{B}\left[q+(1+\pi-\alpha+\cos \alpha) c_{1}\right]
$$

where $\bar{B}$ is the adopted width of foundation, $\mathrm{m} ; q$ the overburden pressure from that side of the foundation in the direction of which the horizontal component of the load is acting, $\mathrm{kPa}$; $c_{1}$ soil cohesion, $\mathrm{kPa} ; \alpha$ the corner. 
$\bar{B}$ is obtained by the formula

$$
\bar{B}=B-2 e_{\mathrm{b}}
$$

where $B$ is width of foundation; $e_{b}$ the load eccentricity relative to longitudinal axis of the foundation.

Under vertical compression $(\alpha=0)$ the formula is written as follows:

$$
N_{\text {ult }}=\bar{B}\left[q+(\pi+2) c_{1}\right]=\bar{B}\left(5.14 c_{1}+q\right) \text {. }
$$

The ultimate bearing capacity of the base $R_{\mathrm{ult}}$ in $\mathrm{kPa}$ is

$$
R_{\mathrm{ult}}=5.14 c_{1}+q .
$$

Then for the case under study:

$$
R_{\mathrm{ult}}=5.14 \times 20+1.7 \times 16=130 \mathrm{kPa} \text {. }
$$

As such, it may be concluded that the catastrophic deformation of the building took place because the planners failed to consider the possible development of unstable conditions in the soils base. The building was subsequently restored to its original position by lifting. Steel coire piles were driven under the longitudinal walls of individual sections (see Chapter 7).

The American experience on reconstruction of historical buildings is stated in the works of Hockton [35] and Robinson [36].

While reconstructing in a built-up area to accommodate erection of new buildings, construction of new foundations near extant buildings results in differential deformations in the latter, followed by the formation of cracks in their walls, especially at places of contact with new structures (Fig. 7). From the data of the Leningrad Civil Engineering Institute (LICI) in St. Petersburg, among the 128 buildings adjacent to which new structures have been built, $80 \%$ have undergone serious deformations, even up to collapse [2]. A similar picture is drawn for Tallin, Tyumen' and other cities. The reasons for such deformations can be chang-

(a)

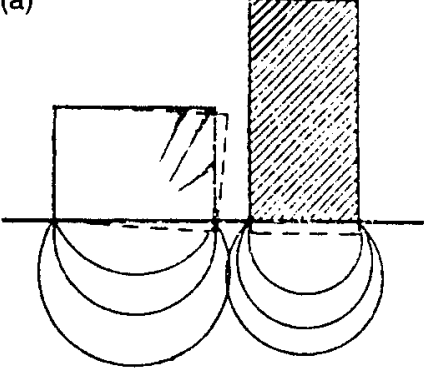

(b)

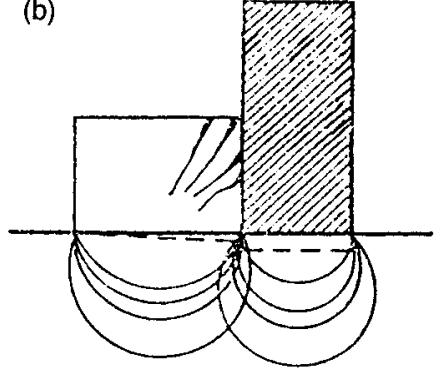

Fig. 7 Deformations of buildings in service due to erection of new buildings (a) adjacent to them and (b) contiguous with them. 
es in the state of stress deformation of bases of in-service buildings as well as the technological effects on them during construction work (vibrations during excavation of trenches, driving of sheet piles, break-up of stability of slope of trenches, freezing of soil and pipes, break-up during water seepage etc.).

Some planning, construction and technological measures are necessary to offset the effects of an 'added-in' building or structure. These measures are listed in the Instructions for Construction of Foundations near Extant Buildings and Structures (St. Petersburg, 1980), prepared by LICI and LenNIIPProekt and in Provisional Instructions for Construction of Foundations Adjacent/Contiguous to Extant Buildings and Structures in Moscow (Moscow, Mosproekt-1, NIIOSP, 1985), prepared by NII Osnovanii.

Changes in the hydrogeological conditions of the site may bring about serious deformations of buildings and structures under service, leading to their failure. Here a rise or fall in the level of groundwater is equally dangerous. It is well known that in a modern city in the vicinity of an industrial undertaking, with time all the new underground utilities (water mains, sewers, heating and telephone connections) are laid, which usually serve the role of drains as well. In some cases they may aid in drainage of saturated soils in the bases, removing the uplift effect which causes soil consolidation under self-weight and additional settlement of structures.

If a building or structure is erected on timber piles, exposure of their tops leads to intensive wood rot, pile splitting under load and considerable uneven settlement of the building. Such a situation was witnessed in Moscow's Mali Theatre when the Neglinka River was led into a pipe and the water table below the base of the building was steeply lowered. Pile rotting was quite intensive and differential settlements set in, leadin $\gamma$ to deformation of the brick masonry walls. Settlement could only be arrested by installing bored piles under the walls of the building. A similar phenomenon was observed in Helsinki where in the central section of the Swedish theatre, consisting of brick masonry buildings of older construction and high architectural value, deformation was so great that serviceability was threatened. All these buildings were built on wooden piles driven into saturated weak soils. But due to the installation of a large number of various engineering utilities in the city the water table fell, uncovering the pile heads which subsequently rotted. Reinforced concrete ('Mega') or steel ('Gustavsberg', 'Bjurstrjöm') multisectional piles have recently been placed under these buildings and their settlements have fully stabilised.

Rise in water table can likewise lead to notable deformation of buildings. This is particularly true of those structures which have loessian soils (collapsible), especially type II in their bases. Under normal conditions, 
with natural moisture content and the water table at depth, the bases of such buildings and structures remain safe. But if the groundwater starts to rise due to leakage from water mains and drains or flooding of irrigated fields, the soils lose their original structure. Most of the salts in the soils are dissolved and the soil with loss of structure becomes a weak, highly compressible, saturated mass. Degradation of loess likewise leads to settlements above the normal values for in-service buildings and measures for strengthening the foundations have to be taken immediately. Such situations have already occurred in Tashkent, Dushanbe, Volgodonsk and elsewhere.

It is worth noting that in the Central Asian republics rise in the water table is not a rare phenomenon but natural and related to flooding of agricultural lands. Observations have shown an average rise in water table of 0.3 to $1 \mathrm{~m} /$ year with a maximum of $3.7 \mathrm{~m} /$ year. This situation must mandatorily be taken into consideration while reconstructing dwellings, civil and industrial buildings and structures in these republics.

In swelling soils wetting may entrain uplift of structures, which usually leads to uneven deformation of the superstructure.

Dynamic activity while driving piles or sheet piles during construction of annexes or constructional activity for strengthening and reconstruction often induces settlement of bases, followed by deformation of existing buildings. Vibration of the foundation soil, especially when made up of sandy soils, causes additional compaction and settlement of foundations. When the regulations for carrying out pile-driving work near extant objects are not followed, the latter may be rendered totally unsuitable for occupancy. Hammers, compressors, vibrators and explosions may elicit undamped deformations of buildings with multitudinous cracks forming in the structures. The proximity of underground metro lines may also have a dangerous effect on near-by buildings.

The entire list of possible causes for the development of deformation of existing buildings and structures should be taken into consideration while planning their reconstruction to preclude repeated reinforcement of bases and foundations. Information about the further deformability of soils in the base, consolidated over long periods under the action of operational load, after reconstruction of a structure, would be of immense practical interest.

Results of measurements of settlements of experimental buildings in the process of adding additional storeys are shown in Figures 8 and 9. The positions of settlement gauges are given in the schematic plan of the building. Graphs of settlement development are depicted along the facade and edges of the walls. Graphs of settlement development are plotted during the period of additional storey construction and during the entire period of observation. The graph for deformation before 


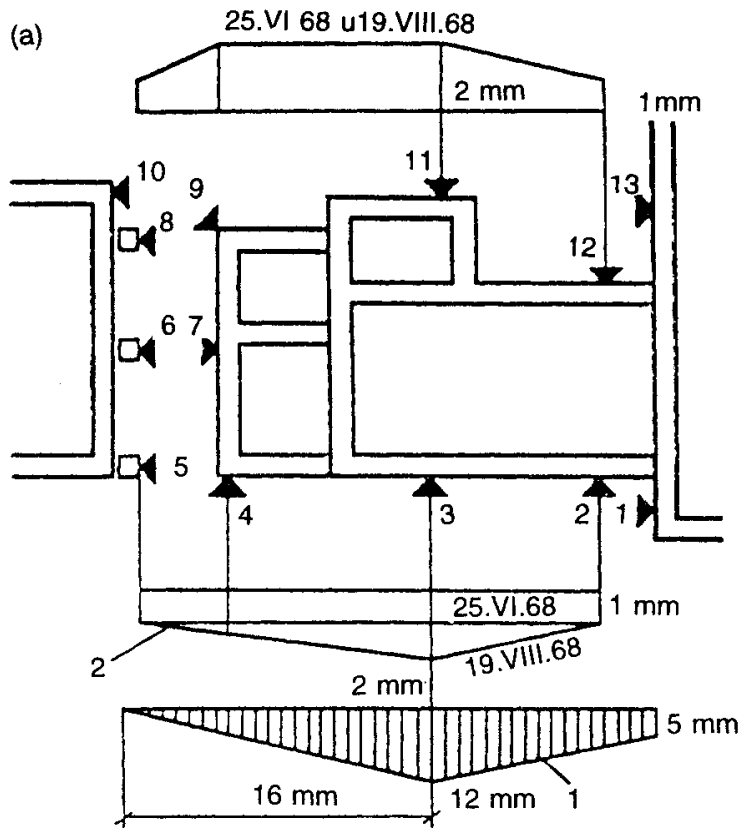

(b)

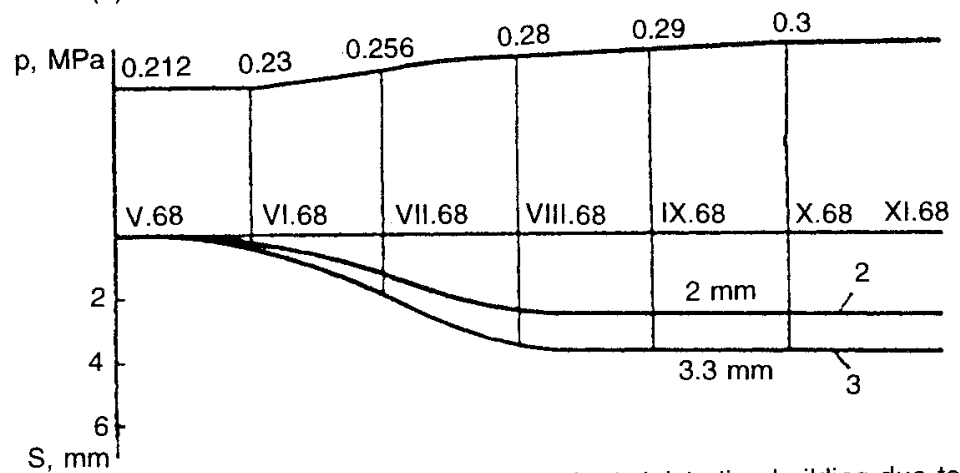

Fig. 8 Results of observations of settlements of administrative building due to upper storey construction (Bolshevitskaya, house no. 13).

a-settlement curves after upper storey construction; b-time-dependent settlement of upper storey building.

1 -settlements measured prior tc upper storey construction from results of levelling windows of 1 st floor; 2-measured deformations after upper storey construction; 3-additional settlement after upper storey construction calculated according to SNiP. 


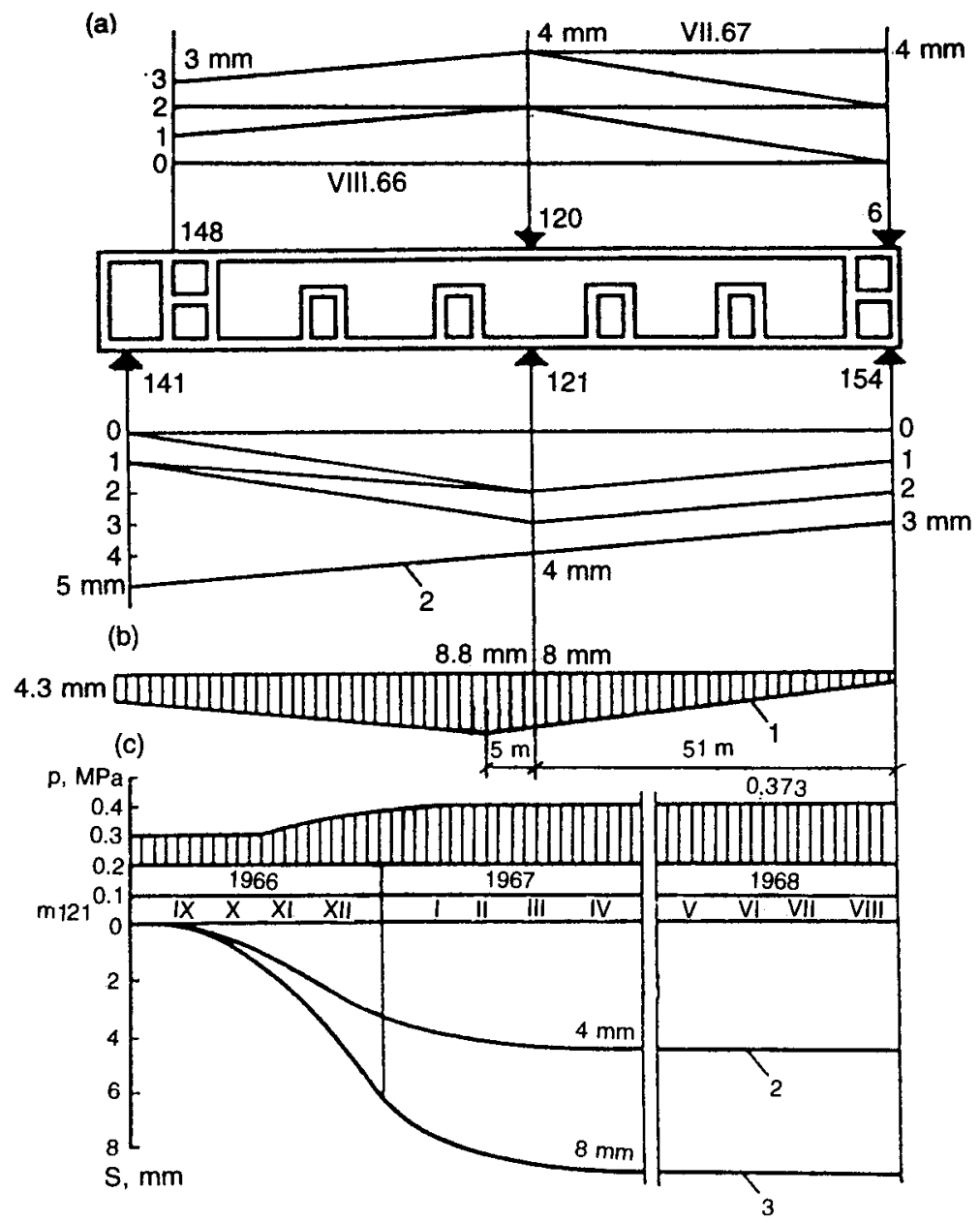

Fig. 9 Settlement observations of building after upper storey construction (Vadkovskii Lane, house no. 12).

1-3: details as in Fig. 8.

construction of the additional storey is given along the wall of the main facade. For that purpose the window sills of the first floor have been brought level. The scheme also shows the increase in load on the base and the average settlement over time. Data on the foundation deformations along those objects are given in Table 1.

Analysis of the data in Table 1 shows that before the additional storey was constructed both buildings had experienced sag. The amount of sag, $f_{\text {rel }}$, was within the permissible limits of the code and the average calculated settlements of the buildings before the additional construction, $S_{p}$ was comparatively less than the code value: $S_{p} / S_{\text {pr.av. }}=0.15$ (Vadkovskii Lane, house no. 12) and $S_{p} / S_{\text {pr.av. }}=0.06$ (Bolshevitskaya, house no. 13). 
Table 1

\begin{tabular}{|c|c|c|c|c|c|c|c|}
\hline \multirow[t]{2}{*}{ Address } & \multirow[t]{2}{*}{$\begin{array}{l}\text { Length } \\
\text { Height }\end{array}$} & \multirow[t]{2}{*}{$f_{\mathrm{rel}}$} & \multicolumn{2}{|c|}{$\begin{array}{c}\text { Calculated } \\
\text { settlement }(\mathrm{cm}) \\
\text { prior to upper } \\
\text { storey construc- } \\
\text { tion }(\mathrm{SNiP})\end{array}$} & \multirow[b]{2}{*}{$\frac{S_{p}}{S_{R}}$} & \multicolumn{2}{|c|}{$\begin{array}{c}\text { Additional } \\
\text { settlement (mm) } \\
\text { upon construc- } \\
\text { tion of additional } \\
\text { storey }\end{array}$} \\
\hline & & & $\begin{array}{l}\text { Under } \\
\text { actual } \\
\text { stress }\end{array}$ & $\begin{array}{l}\text { With } \\
p=R\end{array}$ & & $\begin{array}{l}\text { Calcu- } \\
\text { lated }\end{array}$ & $\begin{array}{l}\text { Mea- } \\
\text { sured }\end{array}$ \\
\hline $\begin{array}{l}\text { Vadkovskii Lane, } \\
\text { House No. } 12 \\
\text { Prior to upper storey } \\
\text { construction }\end{array}$ & 9.16 & $1.6 \times 10^{-4}$ & 11.6 & 27 & 0.43 & - & - \\
\hline $\begin{array}{l}\text { After upper storey } \\
\text { construction }\end{array}$ & 5 & $1.65 \times 10^{-4}$ & - & - & & 8.3 & 4 \\
\hline $\begin{array}{l}\text { Bolshevistskaya St., } \\
\text { House no. } 13 \\
\text { Prior to upper storey } \\
\text { construction }\end{array}$ & 2.72 & $0.75 \times 10^{-3}$ & 4.6 & 12.3 & 0.37 & - & - \\
\hline $\begin{array}{l}\text { After upper storey } \\
\text { construction }\end{array}$ & 1.55 & $0.87 \times 10^{-3}$ & - & - & & 3.3 & 2 \\
\hline
\end{tabular}

Even under the load of $p=R$ the calculated settlements were correspondingly $0.34 S_{\text {pr.av }}$ and $0.15 S_{\text {pr.av }}$. Settlement due to the additional load was equal to $40-60 \%$ of the values due to previously acting loads and proved to be almost 2 times less than half the calculated values; it stabilised very quickly. Due to this the character of uneven settlement did not alter but sag increased. The absolute value of settlement did not exceed 5 to $6 \mathrm{~mm}$ while relative settlement after the additional top construction was nearer to the allowable limiting value for buildings with reinforced brick and reinforced concrete bands.

In both the above cases, buildings located adjacent to the experimental ones to which additional floors were added showed an increase in their settlement in spite of their separation by construction joints. Thus, for additional construction the decisive criterion for determining the possibility of increasing load is not only the value of the average settlement, but also the differential settlement arising from the additional storey construction.

\section{LOAD INCREASE DUE TO BUILDING ADDITIONAL STOREY AND RECONSTRUCTION}

Reconstruction of residential, public and industrial buildings is done to remove their physical and aesthetic deterioration; it is followed by 
strengthening a given construction or changing the building dimensions with additional floor construction or by extension. In carrying out such types of building works it may be necessary to replace or refurbish the fixtures beneath the buildings. In the process of capital repairs and reconstruction of buildings the following may also be undertaken:

-Changes in flooring between storeys, arches, columns, well shafts for staircases, balconys, elements of staircase cells, roofs, coverings, gas and ventilation shafts and similar constructions of prefabricated or massive monolithic reinforced concrete construction.

-Renovation of floors and window openings (in buildings with large head rooms of 3.5-5.2 m) to secure additional floors, whereby the height of rooms in the reconstructed building may be reduced.

- Changes in garret premises and high garrets with additional floors but very little heightening of walls.

-Additional floor construction in buildings without reconstruction or with relaying of floors in the basement section.

The basic type of flooring between storeys in residential and public buildings prior to the October revolution was wooden sheet flooring on wooden beams. The average spacing of wooden beams was $107 \mathrm{~cm}$. Rafters were made from timber logs. Staircase steps were constructed with stone, rarely with reinforced concrete or metal beams built with R.S. joists laid at an angle. In brick buildings with fewer floors wooden staircases were often built.

In some public buildings the roofing consisted of brick arches supported along steel beams. In the case of the monolithic nature of the arches being broken during construction and the need for providing a new floor arose, the steel beams then served the purpose of a rigid framework for ribbed monolithic floors.

The adoption of heavy reinforced concrete elements in place of wooden and steel beams is one reason for increment in dead load on bases and foundations of buildings under reconstruction. Reduction of this load can be achieved by using light-weight concretes of natural or artificial fillers. Replacing the components of concrete with porous fillers of autoclaved cellular concrete will reduce the weight by $0.4-0.5 \mathrm{t} / \mathrm{m}^{3}$ and concomitantly effect a reduction in steel reinforcement.

Glued timber constructions adopted in buildings under reconstruction have shown some promise in reduction of load on foundations. They weigh less, have a high specific strength and rigidity, are corrosion resistant, easily workable and can be prepared in various forms and dimensions.

In providing additional storeys in a building the weight of falsework and protection construction barriers will add additional load to that already existing on the foundations. In a number of cases the load added 
has exceeded the existing load by $30-50 \%$. As such, the number of additional top floors or finally the possibility of reconstruction of the building with increased loads is determined by the bearing capacity of the foundation soils.

Side by side with the increase in dead load on the foundation of buildings under reconstruction, live loads also increase (acting over longer or shorter duration). Further, in the reconstruction and modernisation of a number of industrial establishments erected prior to the October revolution or during the early 5-year plan periods, obsolete equipment was replaced, the number of machines increased and concomitantly the density of their arrangement, as a result of which dead loads increased. Thoroughly re-equipping primarily residential buildings to accommodate various purposes (storage of books, libraries, computer centres, archives, laboratories etc.) has led to a considerable increment in longduration live loads on the floor.

Placing heavy moving carriage and suspended cranes, telphers and loaders as well as the use of cranes during reconstruction and capital repairs, supported on the structure under construction leads to shortterm increase in the load on them in industrial buildings.

Depending on their composition, the loads to be considered in the project are separately categorised. They include (permanent) dead load, long-standing and short-duration loads, with permanent and long-standing loads and the possible short duration of a specific load especially taken into account. The loads to be considered in particular in the last category are those that arise only under special circumstances (seismic, hazardous etc.). Design computations of foundation bases for buildings and structures, including those under reconstruction and increment in loads, are carried out according to two groups of limiting conditions: (1) bearing capacity and (2) deformations (settlement, sag) which hinder normal functioning of the buildings. Design computations for the bearing capacity basically consider the loads and in the presence of specific loads their action on the principal and specific combination. Design computations for deformation of foundation bases should consider the principal essential combination of loads.

As already mentioned, major repairs or reconstruction of in-service buildings are almost always associated with an increase in loads on the foundation bases. If the designs of these buildings are carried out in the same manner as that of bases and foundations for new buildings, then in most cases of reconstruction strengthening the bases and foundations will no doubt be necessary. The procedures for strengthening are labourconsuming, time-consuming and complex, however. Thus cases are known 
wherein reinforcement of bases and foundations was not carried out properly when the load on them was increased, which resulted in the development of uneven building settlement and reduction in its serviceability.

Experience in the reconstruction of residential, public and industrial buildings in a number of cities in our country (Moscow, St. Petersburg, Lvov, Minsk, Ryazan, etc.) has shown that increasing the load is possible without reinforcing the soils in the base or strengthening the foundations if the reserve bearing capacity is utilised. It may be noted that in the earlier codes and in methods of designing foundations and bases considerably smaller allowable loads were adopted than those permitted by the actual bearing capacity. Furthermore, during the service period of a structure the soils in the base are consolidated under the action of loads on the foundation and attain new characteristics. Qualitative assessment of the degree of improvement in the strength and deformation characteristics of these soils enables us to ascertain the additional reserve strength whereby the load on the foundation soils can be increased without soil reinforcement.

It is necessary to design for strengthening or replacing existing foundations only in those situations wherein the above-mentioned increased reserve in the bearing capacity of the base is insufficient. In that case it is best to adopt special methods for reinforcing soils in the base. To elucidate the reserves in the bearing capacity of soils in the base, as a result of lesser code requirements, it is advisable to study and analyse the methods adopted in the earlier designs of foundation bases as well as the allowable loads (as per previous old codes for different soils in bases). This study is imperative for the reconstruction or capital repairs of buildings and structures built prior to the October revolution or World War II. Furthermore, by analysing experience in the construction of upper floors in most houses and by studying the properties of long-term consolidated soils in their bases under foundation loads, we can, with a high degree of confidence, permit higher coefficients in the bearing capacity determined for soils of undisturbed structure.

\section{STANDARDISING STRESS INTENSITY ON FOUNDATION SOILS}

Stress intensity on soils and foundations and dimensions of foundations of buildings were not regulated during the period prior to the October revolution. There were no state norms mandatory for all builders in planning and construction. Allowable stress on the soil was generally decided according to:

- experience in construction in neighbouring districts;

- soil testing by trial loading;

- theoretical formulae of limiting stress on the soil by introducing a small reserve coefficient. 
It is obvious that a reliable value for allowable stress on the foundation soil could only be obtained by considering the results of all three methods. No one method would suffice. Due to practically uncontrolled construction of buildings by individual contracting agencies, the dimensions of foundations and stress intensities on their bases varied widely depending on the qualifications of the specialists and their personal experience, narrow economic interests, and in the best situations were based on the results of soil tests. It is not by accident that in the literature of the period one finds such varying recommended values of allowable stress as $0.15 \mathrm{MPa}$ on dense sandy and clayey soils for one job and $1.0 \mathrm{MPa}$ on dense coarse dry sand in another job.

On the other hand, tables of allowable stress on soils were developed prior to the October revolution for transport engineers. Depending on moisture content and density these varied over a wide range: from $0.05-$ $0.5 \mathrm{MPa}$ for clay and 0.05-0.38 MPa for sand.

In 1926, tentative technical stipulations and norms for planning reinforced concrete structures were approved. The ultimate values of stress in $\mathrm{MPa}$ on foundation soils as approved (depth of foundation varying from 1.5 to $4.0 \mathrm{~m}$ ) are as follows:

Gravel and coarse sand $\quad 0.6$

Dense soils and sand $\quad 0.4$

Dry loose sand $\quad 0.2$

Weak clay soil $\quad 0.1$

Silty soil $\quad 0.05$

When the foundation was laid at a depth of $5 \mathrm{~m}$ the allowable stress was increased by $0.05 \mathrm{MPa}$ and beyond $5 \mathrm{~m}$ an additional $0.025 \mathrm{MPa}$ for every metre.

In 1932, the standards for Construction and Laying of Foundations were finalised (OST 4543) in which the permissible stresses on soils in the foundation were differentiated according to type of soil and its composition. Nearly 60 values of permissible stresses are included in these standards. For each soil type three values are given, depending on the degree of saturation, and for some types of soils two values, depending on the thickness of the layers underneath the foundation. The maximum permissible stress on clay soils was increased to $0.6 \mathrm{MPa}$, which is higher than the values previously recommended.

The values of allowable stresses for sandy soils with layer thickness equal to $1 \mathrm{~m}$ under low moisture and under saturation as given by these standards are presented in Table 2. For a 2-m thick layer of sand, the allowable stress was increased by 0.025 to $0.05 \mathrm{MPa}$ (except for coarse sand, for which the allowable value applies to a layer $4 \mathrm{~m}$ in thickness). 
Table 2

\begin{tabular}{|c|c|c|c|c|c|c|}
\hline \multirow{3}{*}{ Sand } & \multicolumn{6}{|c|}{ Allowable stress on soils, MPas } \\
\hline & Dense & $\begin{array}{l}\text { Medium } \\
\text { dense }\end{array}$ & Dense & $\begin{array}{c}\text { Medium } \\
\text { dense }\end{array}$ & Dense & $\begin{array}{c}\text { Medium } \\
\text { dense }\end{array}$ \\
\hline & \multicolumn{2}{|c|}{ as per Code 1932} & \multicolumn{2}{|c|}{$\begin{array}{c}\text { as per Code } 1938 \text { to } \\
1962\end{array}$} & \multicolumn{2}{|c|}{$\begin{array}{l}\text { as per Code } 1974 \\
\text { to } 1983\end{array}$} \\
\hline $\begin{array}{l}\text { Medium size } \\
\text { Fine low }\end{array}$ & $0.3-0.15$ & $0.225-0.1$ & 0.35 & 0.25 & 0.5 & 0.4 \\
\hline $\begin{array}{l}\text { Ine, low } \\
\text { moisture content }\end{array}$ & 0.2 & 0.15 & 0.3 & 0.2 & 0.4 & 0.3 \\
\hline $\begin{array}{l}\text { Fine, moist and } \\
\text { saturated }\end{array}$ & 0.1 & 0.05 & 0.25 & 0.15 & 0.3 & 0.2 \\
\hline
\end{tabular}

Note: In the graphs of the 1932 code the minimum value corresponds to soils with degree of moisture (saturation) $S_{r}>0.67$ and the maximum for $S_{r}<0.33$.

When the depth of foundation was more than $2 \mathrm{~m}$ the allowable stress value was increased by $0.2 \mathrm{MPa}$ for every additional $1 \mathrm{~m}$ depth (i.e., approximately $0.04 \mathrm{MPa}$ compared to $0.01 \mathrm{MPa}$ as per 1926 standards). For a depth less than $2 \mathrm{~m}$ the allowable stress value was decreased by $0.05 \mathrm{MPa}$ for the shortfall of every metre, but not less than $50 \%$ of the initial value. The effect of a basement on the permissible stresses was not taken into account in these standards, which prescribe the aforesaid values by considering depth of foundation from the natural ground surface.

On the basis of extensive investigations and inspections of old buildings in Moscow built during the 1930s, the erstwhile All-Union Institute of Bases, now NIIOSP, brought out the standard norms OST-9004-38. These indicate that the allowable stress on soils must be determined according to results of investigation, laboratory testing and in-situ test loading, taking into account construction site conditions and sensitivity of the building to uneven settlement.

Test loads and settlement were, in principle, essential in these norms since load testing was considered a more reliable method for prescribing the allowable stress. Stress determination by this method revealed that settlements were in the limits of a linear relation with stress and their values never exceeded $1-3 \mathrm{~cm}$.

Quite possibly, the standard tabulated values of allowable stresses could only be adopted for homogeneous geological stratifications. In the standards under consideration the allowable stresses did not depend upon the thickness of the soil layer underneath the foundation. Tabulated values of allowable stresses for clays and loams were deleted from the 1932 standards. The soils were not subdivided based on density of formation, but instead on degree of moisture content and consistency characteristics (stiff and plastic). The meaning of sandy loams appeared for the first time in the standards and its classification, like that of sands, is based on 
the density index and the moisture content. Similarly, such materials as silty sands were separated for the first time in the standards and the allowable stress values for them are the same as for sandy loams.

The allowable stress values for all types of sands and loams as given in the standards of 1938 remained unchanged in all subsequent standards: NiTU 6-48, NiTU 127-55 (designed strength), SNiP II-B-1-62 (normative stress) and for category III and IV buildings.

SNiP II-15-74, brought into effect from 1975 for the planning of foundations of buildings and structures, differs from the earlier standards. It conditionally permitted higher stresses on all sorts of sands except for fine, silty, wet and saturated. In SNiP 2.02.01-83 values of conditionally permitted stresses for all types of sands and clayey soils remained as before.

The effect of depth of foundation on allowable stress was stipulated for the first time in the standards of 1938. Stresses could be increased by $25 \%$ on the highly loaded edge of eccentrically loaded foundations. The need for computing the settlements of class I structures is mentioned in these standards for the first time and the limiting values of allowable differential settlement between adjacent supports given.

In 1941 (for constructions during the period of World War II) standards were worked out (U-21-41) by simplifying the standards of 1938; however, tabulated values of allowable stresses remained the same except that higher coefficients were brought in for foundation widths greater than $2 \mathrm{~m}$. For a width of $10 \mathrm{~m}$ the coefficient was 2 and for widths between $2 \mathrm{~m}$ and $10 \mathrm{~m}$ the coefficient obtained by interpolation. Stresses on foundation soils for buildings and structures in all cases of reconstruction were increased by $40 \%$ of the allowable stress values as per standards for new constructions. However, it is stipulated that this increase is permissible only if the existing structure is free from cracks due to differential settlements.

Compared to the standards of 1938, those of 1948 (NiTU 6-48) introduced a series of changes. Stipulation of the region in which tabulated values of allowable stresses could be adopted was eliminated (distributed in soils of heterogeneous bases). Tabulated values of allowable stresses were given for foundation widths of 0.6 to $1.0 \mathrm{~m}$. Higher coefficients for foundation width exceeding $1 \mathrm{~m}$ were introduced. The allowable stresses for clay soils including sandy loams were differentiated on the basis of void ratio. But in general the novelty of the 1948 standards is that in the earlier ones values of allowable stresses relate only to accounting for the action of principal loads. In that year considerably higher values of allowable stresses (by 0.02-0.05 MPa) were permitted for both principal and additional (short-duration) load combinations and in the case of action of the overall combination of loads the allowable stress ranges from 0.03 to $0.1 \mathrm{MPa}$. 
In the Preface to the 1948 standards the need for taking the character and composition of acting loads into account is described; further it is also necessary to consider not only the allowable stress, but also the possible development of impermissible deformations. In the standards of 1955 (NiTU 127-55) similar dependence of allowable stress on loads (termed 'design resistance') is removed, however. These standards include the principles of designing foundations according to the second limiting condition (based on deformation). Tables for limiting settlements of foundation bases for different buildings and structures are presented. When the width of foundation is more than $3 \mathrm{~m}$, the design resistance of the soil in the base is dependent on the shear strength characters $c$ and $\phi$ of soil and likewise on the dimensions of the foundation (however, for smaller foundations, characteristic of mass scale construction, the tabulated values of design resistance of soil are kept unaltered). The basis for classifying sands as dense, medium dense and loose was changed in these standards. In place of the relative density index, according to Terzaghi, sands are classified into groups based on the void ratio.

In SNiP II-B-1-62, calculations according to the second limiting condition (deformation) are further improved. It is taken that the calculated settlements should not exceed the limiting values given in the standards and the average stress on the base of the foundation (from standard loading) should not exceed the normative stress on the soil in the base.

Tabulated values of normative stress $R_{0}$ equal to the computed resistance of the 1955 standards were adopted in the new SNiP for deciding the preliminary dimensions of foundations of class I and II buildings and structures and the final dimensions of foundations of class III and IV buildings and structures. This data could be used for foundations in which the width of footing varied from 0.6 to $1.5 \mathrm{~m}$ and foundation depth from 1.0 to $2.5 \mathrm{~m}$, discounting any basement in the building. No corrections were made for any other width or depth of foundation. Instead, in SNiP II-B-1-62, an equation for determination of allowable stress on the base is included, i.e.,

$$
R_{N}=(A b+B h) \rho_{0}+D c_{N}
$$

where $A, B, D$ are non-dimensional coefficients depending on the design value of angle of internal friction $\phi_{N} ; b$ the width of the rectangular foundation, $\mathrm{m} ; h$ the foundation depth in $\mathrm{m}$ from the natural ground level or the finished ground level and up to the bottom of the foundation; $\rho_{0}$ the density of soil in $\mathrm{g} / \mathrm{cm}^{3}$ of the soil layer above the base of the foundation; $c_{N}$ the design value of soil cohesion in $\mathrm{MPa} / \mathrm{m}^{2}$ for clay or the design parameter of linearity for sands laying directly beneath the foundation. 
Allowable (normative) stress on the base should be taken to mean the average stress beneath the foundation due to which zones of failure of strength up to a depth of $1 / 4$ the width of the foundation develop at the corners of the latter. Exceeding the stress as indicated by the normative stress value makes it impossible to carry out calculations of foundation settlement of buildings and structures by the standard formula according to the theory of elasticity.

As shown by design practice, the allowable stress, calculated by the given equation, is practically higher than the values allowed previously for stress and calculated strengths. Particularly large variations in values are observed in cases of foundations laid deep on soils with higher values of angle of friction or cohesion, which permit full utilisation of the bearing capacity of foundation soils. The effects of a basement on allowable stresses are taken into account in the standards by a special equation along with equation (3), differing from it only in the second term.

The positive aspect of the 1962 standards is that the limiting value of foundation deformation enabled determination of settlements while taking into consideration the effect of stress conditions of the construction, horizontal deformation, tilting and deformation of the foundation body, and service conditions of the structure.

As in NiTU-127-55, in SNiP-II-15-74 correction coefficient factors were introduced for permissible stress values for foundations with a width $1 \mathrm{~m}<b \leq 1 \mathrm{~m}$ and foundation depth $2 \mathrm{~m}<h \leq 2 \mathrm{~m}$. The useful field of tabulated values of design stresses remains the same as that for permissible stresses given in SNiP II-B-1-62.

The equation for determination of design stress for foundations is essentially changed in SNiP II-15-74 compared to that given in SNiP II-B-162. Values are incorporated in it which clearly take into account the presence of a basement and also the working conditions of the building or structure (along with the foundation base):

$$
R=\frac{m_{1} m_{2}}{k_{r}}\left(A b \rho_{\mathrm{II}}+B h \rho_{\mathrm{Il}}+D c_{\mathrm{II}}-\rho_{\mathrm{II}}^{\prime} h_{0}\right)
$$

where $m_{1}, m_{2}$ are coefficients of working conditions corresponding to soil in the base and building or structure mutually with the foundation; $k_{r}$ is the reliability coefficient; $h$ depth of foundation from planned level of excavation or fill, $m$; $\rho_{11}^{\prime}$ the average density of soil (for each layer) lying above the level where the foundation is laid, $\mathrm{g} / \mathrm{cm}^{3} ; \rho_{\mathrm{II}}$ the same but for layers below the foundation level, $\mathrm{g} / \mathrm{cm}^{3} ; c_{\text {II }}$ the computed ultimate cohesion of soil lying directly beneath the foundation, MPa; $h_{0}$ the depth up to floor level of the basement, $\mathrm{m}$; in the absence of a basement floor $h_{0}=0$. 
As per the present operative SNiP 2.02.01-83, the design value of soilbearing capacity $R$ is determined by the equation

$$
R=\frac{\gamma_{c 1} \gamma_{c 2}}{k}\left[M_{\gamma} k_{z} b \rho_{\mathrm{II}}+M_{q} d_{1}^{\prime} \rho_{\mathrm{II}}+\left(M_{q}-1\right) d_{B} \rho_{\mathrm{II}}^{\prime}+M_{c} c_{\mathrm{II}}\right]
$$

where $\gamma_{c 1}, \gamma_{c 2}$ are coefficients of working condition; $k$ is a coefficient equal to 1 if the strength properties are determined directly by experiments, and equal to 1.1 if taken from the tables; $M_{\gamma^{\prime}} M_{q}, M_{c}$ are coefficients depending on the angle of internal friction; $k_{z}$ a coefficient dependent on the width of foundation $b ; \rho_{\text {II }}$ the average density of soil beneath the foundation level taking into account the uplift of water; $\rho_{\text {II }}^{\prime}$ the same for soils above the foundation level; $d_{1}$ the depth of foundation for a structure without basement from the planned level or the depth adopted for laying the outer and inner foundations from the basement floor; $d_{b}$ the basement depth, i.e., distance between planned level and basement floor; $c_{\text {II }}$ the design maximum cohesion of soil lying directly beneath the foundation bottom.

It can be seen from the structure of the equation for bearing capacity of soils as per the 1983 standards that it hardly differs from the equations of the 1974 standards. At the same time it takes into account the buoyancy effect of water for soils in the base; further, the correction coefficient $k_{z}$ is introduced, which considers the effect of the zone of plastic deformation in the bases of foundations of different bottom widths. In addition, there is to some extent an increase in the value of the conditionally designed stress on coarse gravels and gravelly soils.

In our Russian standards, allowable stresses, design strength, safety stress, etc. for soils have undergone changes and in a number of cases have even been notably increased. But as a rule they do not exceed the values adopted abroad (particularly for sandy soils). At the same time considerably higher allowable stresses on plastic and soft plastic soils are permitted in Russia, which according to the standards of a number of countries are generally not allowed. Experience in construction on such soils has confirmed the validity of the recommendations made in our Russian standards.

Values of design stresses on foundation soils contained in the Russian standards and those of other countries are shown in Table 3 (as given in 1983).

It is clear from Table 3 that further increment in allowable stress on sandy and clay soils of different consistencies, from stiff to stiff plastic, is possible, but naturally only after a thorough analysis of constructional experience under increased stresses. Such work was done in part for the engineering-geological conditions of Moscow during 1965-1971. Subse- 
quently Instructions for Planning Bases and Foundations of Residential Buildings under Increased Allowable Stresses on Soils for the Engineering-geological Conditions of Moscow was prepared by NII and for bases and underground structures with the participation of the management of Mosproekt-1. Practical experience has confirmed that the propositions given in the instructions are applicable not only in Moscow, but in other cities with similar soil conditions as well.

Extensive indigenous experience in reconstruction notwithstanding, there are presently no standards or regulations for designing bases and foundations for buildings under reconstruction. Nor is there a single document delineating the engineering exploration to be carried out in a group of complex works during investigation of buildings under service. In the 1930s, while elucidating the possibility of further storey construction in buildings, the following assumptions were made:

- stress at the base of footings after additional storey construction should not exceed the allowable values as per the standards for designing foundations for new structures;

-the thickness of the homogeneous soil layer in the base of a building or structure should be quite large;

- soils in the foundation are not to be eroded by ground or other waters;

-compressibility of the base should not be much and should be uniform in plane area.

The new stress on foundation soils consolidated under long-term load from the building was calculated as the allowable stress (design, standard) with an increased coefficient 1.1-1.5, depending on the type of soil, and taken for new structures.

During these years the permanent commission established to study the possibility of increasing stress on the foundation soil of buildings in service, depending on the service period of the structure, was operative in St. Petersburg. Practical studies by the permanent commission enabled it to conclude that the increase in load compared to the actually acting one for soils could be: $20-30 \%$ for clays, $40-60 \%$ for medium coarse sands and up to $100 \%$ for coarse-grained sands. Concomitantly the literature of this period pertaining to building repairs took a more cautious approach to increasing the maximum coefficient and sometimes even proposed that new stresses should not exceed the permissible values given by standards and ought even to be less in the case of a guarantee. Experience in construction and reconstruction during the period of World War II proved that higher stresses could be adopted.

From 1947 increased stresses of $25 \%$ on foundations for transport constructions were permitted, if they had served for a period of not less than 20 years and there were no discernible defects. SNiP II-B-1-62 likewise 


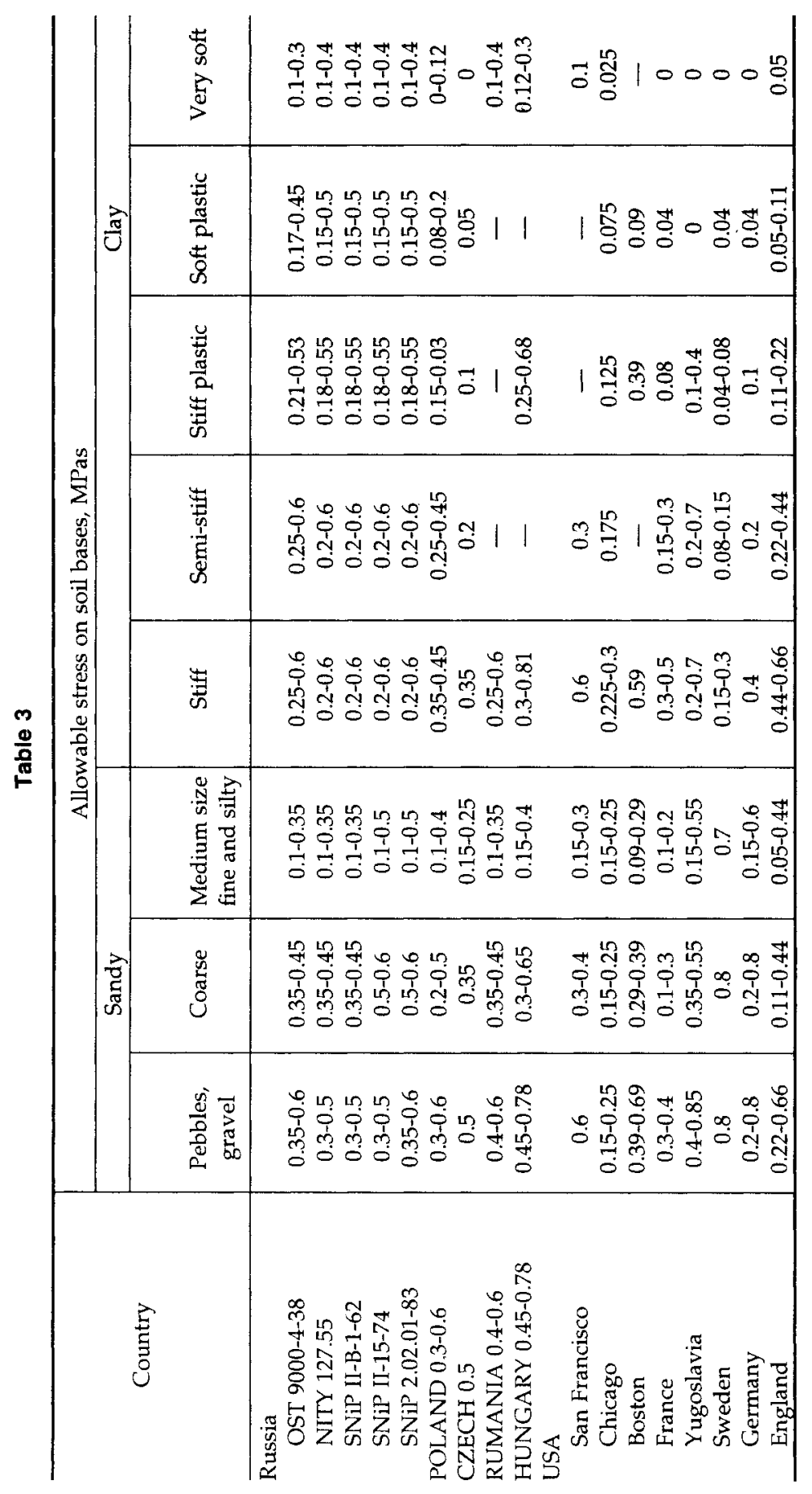




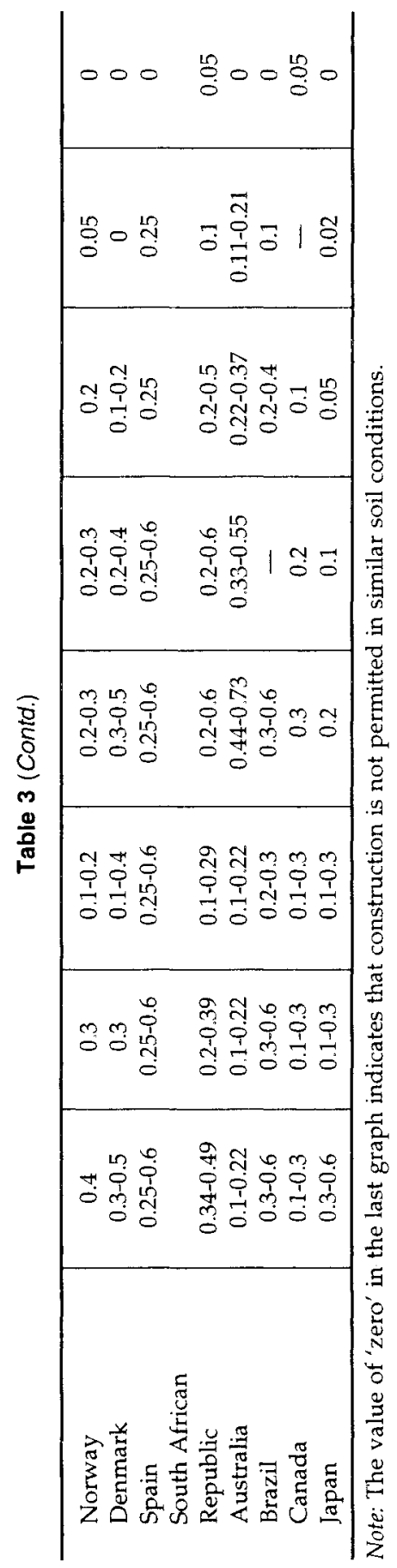


permitted an increase in permissible stress on soil under existing foundations of up to $20 \%$ if they had sufficient strength.

In the 1974 and 1983 SNiPs there are no concrete recommendations regarding increase in design stress on soils in foundations of buildings under service. The absence of such recommendations precluded establishing when and by how much stress on soils in bases under extant foundations could be increased. Yet practical experience in additional floor construction carried out successfully without strengthening foundations or artificially reinforcing foundation soils showed that stress on foundation soils could almost always be increased and that, too, up to considerable limiting values.

E.V. Polyakov (1972) and V.K. Sokolov [3], summarising several experiences in the reconstruction of residential buildings, proposed that strength of soils in bases be determined by taking into account their compression during the service period, guided by the results of all-round investigations of the condition of the existing structure and characteristics of the soils under its foundation. To determine the possibility of building upper floors, in other words for preliminary computation of new values of allowable stress on the consolidated soils in the bases $R^{\prime}$, they recommended that the following equation be adopted:

$$
R^{\prime}=k R_{N}
$$

where $k$ is the coefficient of increase in soil strength depending on the ratio $p_{0} / R_{N}$ (here $p_{0}$ is the actual stress on soils in the base before construction of a storey, $\mathrm{MPa}$ ); $R_{N}$ the normative design strength of soil in the base determined as for a new structure, MPa.

Values of coefficient $k$ are as given below:

$$
\begin{array}{cccccccccccc}
p_{0} / R_{N} & 1.0 & 0.9 & 0.8 & 0.7 & 0.6 & 0.5 & 0.4 & 0.3 & 0.2 & 0.1 & 0 \\
k & 1.5 & 1.45 & 1.4 & 1.35 & 1.3 & 1.25 & 1.2 & 1.15 & 1.1 & 1.05 & 1.0
\end{array}
$$

For enhancement of the coefficient of strength $R$ the following conditions should be considered:

-the service period of the building for which superstorey construction is being considered should be not less than: 3 years for sandy soils, 5 years for sandy loams and loams and 8 years for clays;

- there should be no cracks in the building, deformation or similar indications of differential settlement.

If the new actual stress $p^{\prime}$ is more than $R^{\prime}$, then widening of the foundation bottom, strengthening the soil base, or reducing the weight of the superconstruction are recommended. But though adoption of the enhanced coefficient for the value of allowable stress in the design of foundations of buildings under reconstruction (derived only from their service age and actual stress on soils in the bases before reconstruction) appears simple and clear, the problem of the safety of the building is not fully 
resolved since the possible deformations have not been taken into account. Nor have the permissible limit of settlement for the specific type of building to be reconstructed and its capacity to resist uneven settlement been considered in the calculations.

Future work on the design of foundations for buildings under reconstruction should take the aforesaid aspects into consideration and be based on the principle of designing foundations according to the two groups of limiting conditions, namely, strength and deformation, which lead to hindrances in normal functioning of the building. With that objective in mind, it is necessary to investigate the conditions of the bases and foundations of a large group of buildings under reconstruction in order to ascertain the following:

-change in stresses of fourdation soils after reconstruction of the building;

- complete picture of the strength and deformation characteristics of soils in the bases before restructuring;

- processes that have occurred in the soils in the bases under longterm loading;

-actual condition of the soils in the foundations under reconstruction;

- deformations of the building before and after reconstruction and also their share in the allowable limiting values of deformation of buildings. 
investigation is warranted into the functioning of some mechanical industries which specialise in the production of machines and hoisting equipment for foundation construction. In the first place, it might be possible to increase production of some of the machines already under use by construction organisations, which have functioned well in reconstructions.

To conclude, let us say a few words about the normative documents (codes) regulating the process of stabilising bases and strengthening foundations of buildings and structures under reconstruction. These documents are presently in the working stage. In our opinion, these norms should not seek to impose strict regulations on all the stages of computation and project design. The principles of design of foundations should be firmly maintained by the two groups of limitations, namely, bearing capacity and deformation. It is possible and would be well worthwhile to bring out a code for determining the new design strength (resistance) of soil which has been compressed under the foundations due to the action of a long-term load. The volume and places of location of soils in bases, for which the physicomechanical properties are determined by one or the other method, should be indicated. The document should probably also include tables of limiting additional values of total and differential deformations of buildings and structures under reconstruction (similar ones have been presented in Chapter 5). At the same time, planners should have some latitude for computing themselves the additional deformations of buildings, taking into account the peculiarities of the construction, its interactive working with the utility systems and specificity of construction technology. As for computations for pile foundations, our viewpoint has already been given above. The document should also include one or two of the computation schemes worked out by specialists in chemical stabilisation of soils.

It is fully feasible for the planners and designers to translate the recommended norms of computational schemes into computer language. This would considerably augment a general transition to alternative design and selection of the most economical and technically sound procedures.

\section{REFERENCES}

1. Konovalov, P.A. 1980. Ustroistvo fundamentov na zatorfovannykh gruntakh [Construction of Foundations on Peaty Soils]. Stroiizdat, Moscow, $160 \mathrm{pp}$.

2. Simazin, G.V. 1983. Osobennosti proektirovaniya i vozvedeniya fundamentov okolo sushchestvuyushchikh zdanii [Specialities of Planning and Building Foundations Adjacent to Existing Buildings]. Izd-vo. Gos. Un-ta, Petrozavodsk, 55 pp.

3. Sokolov, V.K. 1986. Modernizatsiya zhilykh zdanii [Modernisation of Residential Buildings]. Stroiizdat, Moscow, $151 \mathrm{pp}$.

4. Osnovaniya gidrotekhnicheskikh sooruzhenii. Normy proektirovaniya [Foundations of Hydrotechnical Structures. Standards for Design Planning]. SNiP II-16-76. 
5. Trofimenkov, Yu.G. and L.N. Vorobkov. 1981. Polevye metody issledovaniya stroitel'nykh svoistv gruntov [Field Methods of Investigating the Engineering Properties of Soils]. Stroiizdat, Moscow, 215 pp.

6. Metodika obsledovaniya i proektirovaniya osnovanii i fundamentov pri kapital'nom remonte, rekonstruktsii i nadstroike zdanii [Method of Investigation and Design of Bases and Foundations in Capital Repairs, Reconstructions and Superstorey Construction of Buildings]. Stroiizdat, Moscow, 111 pp. (1972).

7. Prokhorkin, S.F. 1981. Rekonstruktsiya promyshlennykh predpriyatii [Reconstruction of Industrial Enterprises]. Stroiizdat, Moscow, $124 \mathrm{pp}$.

8. Ganichev, I.A. 1981. Ustroistvo iskusstvennykh sooruzhenii i fundamentov [Erection of Artificial Structures and Foundations]. Stroiizdat, Moscow, 543 pp.

9. Gendel', E.M. 1980. Inzhenernye raboty po restavratsii pamyatnikov arkhitektury [Engineering Works in the Restoration of Architectural Memorials]. Stroiizdat, Moscow, $198 \mathrm{pp}$.

10. Dmitriev, N.V., L.I. Malyshev and Yu.I. Spitsyn. 1986. Usilenie osnovanii i fundamentov zdanii Gosudarstvennoi Tret'yakovskoi galerei [Strengthening bases and foundations of the Government Tret'yakovskoi gallery]. Osnovaniya, Fundamenty i Mekhanika Gruntov, no. 4, pp. 6-8.

11. Rekomendatsii po proektirovaniyu i stroitel'stvu shchelevykh fundamentov [Recommendations for Design and Construction of Slot Foundations]. NIIOSP, Moscow (1982).

12. Rzhanitsyn, B.A. 1985. Khimicheskoe zakreplenie gruntov v stroitel'stve [Chemical Stabilisation of Soils in Constructions]. Stroiizdat, Moscow.

13. Artyushina, V.H. and D.A. Gubkina. 1986. Opyt rekonstruktsii tsekha termofosfornoi kisloty PO 'Khimprom' $v$ Slavyanske [Experience in reconstruction of a thermophosphoric acid plant for Khimprom in Slavyansk]. Osnovariya, Fundamenty i Mekhanika Gruntov, no. 4, pp. 8-9.

14. Smorodinov, M.I. and V.H. Korol'kov. 1984. Struinaya tekhnologiya ustroistva protivofil'tratsionnykh zaves i nesushchikh konstruktsii v grunte [Jet technology of building antiseepage curtains and load-bearing constructions in soil]. Tekhnologrya Stroitel'nomontazhnykh Rabot, no. 1, 41 pp. VNIIIS Gosstroya SSSR.

15. Khasin, M.F., L.I. Malyshev and I.I. Broid. 1984. Struinaya tekhnologiya ukrepleniya gruntov [Jet technology of strengthening soils]. Osnovaniya, Fundamenty i Mekhanika Gruntov, no. 5, pp. 10-12.

16. Afonin, V.G., L.M. Geiman and V.M. Komar. 1982. Spravochnoe posobie po vzryvnym rabotam v stroitel'stve [Handbook for Blasting Works in Construction]. Budivel'nik, Kiev.

17. Metodicheskie ukazaniya po razrusheniyu materiala razbiraemykh stroitel'nykh konstruktsii [Methodological Instructions for Demolition of Material in Dismantling Building Constructions]. NIISP, Kiev (1984).

18. Buzov, G.S. and P.P. Bessolov. 1985. Sovremennoe sostoyanie i tendentsii razvitiya bol'shikh gorodov v SSSR i za rubezhom: Ekspress. inform [Modern status and development tendency of larger towns in the USSR and abroad. Express information]. MGTsNTI, Moscow, no. 5.

19. Kort, D., Yu. Linnok and R. Dekekhaimer. 1985. Organizatsiya rabot po snosu zdanii [Organisation of Works for the Demolition of Buildings]. Stroiizdat, Moscow.

20. Metodicheskie rekomendatsii po razrusheniyu betonnykh i zhelezobetonnykh fundamentov ornestruinym i elektrogidravlicheskim sposobami [Methodological Recommendations for Demolishing Concrete and Reinforced Concrete Foundations by Gas Jet and Electrohydraulic Means]. TPO 'Bashneftekhimzavoda', Ufa (1983).

21. Instruktsiya po zabivke svai vblizi zdanii i sooruzhenii [Instructions for Driving Piles Near Buildings and Structures]. VSN 358-76, Moscow. 
22. Instruktsiya po proektirovaniyu i ustroistvu fundamentov iz svai v rubashke [Instructions for Designing and Erecting Piles in Jacket Foundations]. VSN 65.03-81. NIIPromstroi, Ufa (1981).

23. Posobie po proizvodstvu rabot pri ustroistve osnovanii i fundamentov [Guidance for Carrying Out Works in the Formation of Bases and Foundations]. SNiP 3.02.0183. Stroiizdat, Moscow, $567 \mathrm{pp}$.

24. Sotnikov, S.N., V.G. Simazin and V.P. Vershinin. 1986. Proektirovanie i vozvedenie fundamentov vblizi sushchestvuyushchikh sooruzhenii [Planning and Constructing Foundations Adjacent to Existing Structures]. Stroiizdat, Moscow, $96 \mathrm{pp}$.

25. Ukazaniya po ustroistvu fundamentov okolo sushchestvuyushchikh zdanii i sooruzhenii [Instructions for Laying Foundations Next to Adjacent Buildings and Structures]. ONTILenNIIproekt, Leningrad, $56 \mathrm{pp}$. (1980).

26. Shvets, V.B., V.I. Feklin and L.K. Ginzburg. 1985. Usilenie i reconstruktsiya fundamentov [Strengthening and Reconstruction of Foundations]. Stroiizdat, Moscow, $272 \mathrm{pp}$.

27. Plagemann, W. and W. Langer. 1948. Die Gründung von Hock- und Ingenierbauten. Leipzig.

28. Sanace podlozi tunelovich peci ve velkich opatovicich. Vodni Stavbi (1981).

29. Wikström, R.G.M., J.T. Heikkilä, P.K. Paavola and M.K. Pelkkikangas. 1985. The influence of vibrations on the Athenaeum. Proc. 11th International Conf. Soil Mechanics and Foundation Engineering, San Francisco, vol. 3, pp. 1499-1502.

30. Schlosser, F., J.P. Magnan and R.D. Holtz. 1985. Geotechnical engineering construction. Proc. 11th International Conference Soil Mechanics and Foundation Engineering, San Francisco.

31. Van Impe, W.F. 1991. Deformations of deep foundations. CEMSTF, vol. III. Firenze.

32. Frank, R. 1991. Some Recent Developments in the Behaviour of Shallow Foundations. Firenze.

33. World Geological Guide. ICSMF, vol. XII (1989).

34. Tien, N.T., P.D. Long, T.V. Cuong and T.D. Ngoc. 1991. Foundation Methods in Densely Populated Areas. Bangkok, Thailand, vol. 1. 